\title{
Echinoderm research perspectives: A Central American bibliometric review
}

\author{
Juan José Alvarado ${ }^{1,2,3}$ \& Sònia Fabregat Malée ${ }^{1,4}[D$
}

1. Centro de Investigación en Ciencias del Mar y Limnología (CIMAR), Universidad de Costa Rica; 2060-1000 San Pedro de Montes de Oca, Costa Rica; juan.alvarado@ucr.ac.cr

2. Escuela de Biología, Universidad de Costa Rica, 2060-1000 San Pedro de Montes de Oca, Costa Rica.

3. Centro de Investigación en Biodiversidad y Ecología Tropical (CIBET) (previously Museo de Zoología), Universidad de Costa Rica, 2060-1000 San Pedro de Montes de Oca, Costa Rica.

4. Posgrado en Biología, Sistema de Estudios de Posgrado, Universidad de Costa Rica, 2060-1000 San Pedro de Montes de Oca, Costa Rica; soniafabregat.m@gmail.com

Received 27-V-2021 • Corrected 30-IX-2021・ Accepted 26-X-2021

DOI: https://doi.org/10.22458/urj.v13i2.3535

\begin{abstract}
Introduction: Central America, a narrow strip of land dividing the Atlantic and Pacific oceans, has a high diversity of marine and terrestrial species. Echinoderms are one of the most diverse marine groups with 420 reported species. Objective: To summarize echinoderm research in Central America. Methods: We compiled the literature from SCOPUS, Web of Science, SciELO, Google Scholar, Biodiversity Heritage Library, the Internet Archive and the Smithsonian Library. Results: We found 324 publications dating from 1840 to 2020; the early studies had a strong taxonomic focus, but after the 1970s, ecology, evolution and reproduction gained prominence. Echinoidea is the most studied class ( $38 \%$ of publications) due to its use in evolutionary studies as well as the importance of the genus Diadema in reef ecology and dynamics. Conclusion: We recommend more research on fisheries management, conservation and environmental education; and greater integration of local and international research.
\end{abstract}

Keywords: Ecology, Echinoidea, evolution, Diadema collaboration networks.
RESUMEN. "Perspectivas en investigación de equinodermos: una revisión bibliométrica en Centroamérica". Introducción: Centroamérica, una estrecha franja de tierra que divide los océanos Atlántico y Pacífico, tiene una gran diversidad de especies marinas y terrestres. Los equinodermos son uno de los grupos marinos más diversos con 420 especies reportadas. Objetivo: Resumir la investigación sobre equinodermos en Centroamérica. Métodos: Recopilamos la literatura de SCOPUS, Web of Science, SciELO, Google Scholar, Biodiversity Heritage Library, Internet Archive y Smithsonian Library. Resultados: Identificamos 324 publicaciones que datan de 1840 a 2020; los primeros estudios tenían un fuerte enfoque taxonómico, pero después de la década de 1970, la ecología, la evolución y la reproducción ganaron importancia. Echinoidea es la clase más estudiada ( $38 \%$ de las publicaciones) debido a su uso en estudios evolutivos, así como a la importancia del género Diadema en la ecología y dinámica de arrecifes. Conclusión: Recomendamos más investigación sobre manejo pesquero, conservación y educación ambiental; y una mayor integración de la investigación local e internacional.

Palabras clave: Ecología, Echinoidea, evolución, Diadema, redes de colaboración.

Central America is a narrow strip of land dividing the world's two largest oceans: Atlantic and the Pacific (Cortés, 2007). It includes seven countries: Belize, Guatemala, El Salvador, Honduras, Nicaragua, Costa Rica and Panama; and has an Exclusive Economic Zone of $1518705 \mathrm{~km}^{2}, 156$ $251 \mathrm{~km}^{2}$ of continental platform and $6603 \mathrm{~km}$ of coastline (Alvarado et al., 2013; Coppard \& Alvarado, 2013; Coppard \& Lessios, 2017). The region is highly rich in coastal ecosystems, which include carbonate platforms, soft and rocky bottoms, coral environments, seamounts, coastal and oceanic islands, gulfs and coastal upwelling areas, among other geomorphologic and oceanographic features, all of which translate to a high diversity of organisms (Cortés, 2007). 
One of these highly diverse groups is the phylum Echinodermata. Echinoderms are deuterostome invertebrates that are only found in marine environments (including mangroves, coastal lagoons and anchialine caves). The phylum is characterized by pentamerous radial symmetry, a carbonate skeleton, a water vascular system used for feeding and movement, and a great ability to regenerate their tissues (Pawson, 2007). These organisms have colonized every marine environment, from the depths of abyssal plains to shallow coastal areas, fulfilling a wide range of key ecological roles, as herbivores, predators and filter feeders (O'Hara \& Byrne, 2017). More than 7,000 echinoderm species have been identified worldwide, and they belong to five extant classes (Crinoidea, Asteroidea, Ophiuroidea, Echinoidea and Holothuroidea) (Pawson, 2007). In over 180 years of research, 420 species have been named (Alvarado et al., 2013; Coppard \& Alvarado, 2013; Coppard \& Lessios, 2017; Cambronero-Solano et al., 2019).

Echinoderm research in the region began in the mid-19th and early 20th centuries with scientific expeditions from the United States that produced a great variety of monographs containing multiple species descriptions. Most of these documents are available through the Biodiversity Heritage Library (Biodiversity Heritage Library, 2021). In the second half of the 20th century, the increasing development of universities and research centers enabled scientific publications to proliferate. Some of these papers, however, remained buried in grey literature or were only published in minor local journals, making them difficult to trace.

Bibliometric tools and literature search engines, such as SCOPUS and ISI Web of Science, have provided a more extensive analysis of scientific products, and have helped to draw attention to publications that otherwise might have remained unnoticed. The goal of this study is to quantify scientific literature regarding echinoderms in Central America to identify research needs, as well as to detect and strengthen lines of research that already exist in the region.

\section{MATERIALS AND METHODS}

We used: SCOPUS, ISI Web of Science, SciELO, and Google Scholar. Combinations of the names of Central American countries and echinoderm class names or the derivatives of phylum name "Echinodermata" were used as keywords. Example search terms could be constructed as follows: Ophiuroidea AND Panama, Crinoidea AND Honduras, Holothuroidea AND Central America. Searches considered the title and abstract as well the whole text of the document. Literature was subsequently examined to check if it included a real reference to the region and echinoderms. Likewise, a literature search was made in the Biodiversity Heritage Library (https://www.biodiversitylibrary.org/), the internet archive (https://archive.org/) and the Smithsonian Library (https://library.si.edu/) to cover monographs published in the 19th and early 20th centuries. Only those works that explicitly indicate the collection and analysis of material from Central America were considered.

The publications were classified in a database in which different variables were considered:

1) coast (Pacific, Caribbean or both); 2) country (Belize, Guatemala, Honduras, El Salvador, Nicaragua, Costa Rica, Panama or all Central America); 3) source (journal, thesis, report, book chapter or book); 4) taxonomic class (Crinoidea, Asteroidea, Ophiuroidea, Echinoidea, Holothuroidea, or more than two); 5) research topic (taxonomy, parasitism, reproduction, physiology, ecology, fisheries, diversity, evolution, and environmental education); 6) name of first author; 7) nationality of authors (Central American, Foreign, or collaboration between Central Americans and authors of other nationalities); 8) number of authors (1, 2, 3, 4, 5, >5); and 9) gender of authors (male or female). For research topics, a study could be classified into more than one topic if it applied. For the authors' nationalities, we use their affiliation. 


\section{RESULTS}

In accordance with the search criteria, 324 documents were identified (supplementary materials), dating from 1840 to 2020 . These publications were primarily found in scientific journals, book chapters, books, conference proceedings, and reports. Six scientific journals contained $33 \%$ of these publications. The rest of publications are distributed in 116 journals. Of these six, the journal containing the most publications that fit the search criteria was the Revista de Biología Tropical (9,3\%), followed by the Bulletin of Marine Sciences (6,2\%), Marine Biology (4,9\%), Evolution, Coral Reefs, the Journal of Experimental Marine Biology and Ecology (with 3,1\% each). 87\% of these studies were published since the 1970s (Fig. 1A). From 1840 to 1969, one to seven scientific works on the subject were published per decade. Most of the publications were monographs or expedition memoirs. From a geographic standpoint, most publications were carried out in the Caribbean (154) while 116 publications cover the Pacific coast. There are 53 studies that encompass both coasts. The Pacific coast was the most researched region until the 1960's (31 publications). In the last four decades, focus has shifted to both coasts with a total of 44 scientific publications.

The first 100 years of scientific research were mainly focused on works throughout the region (Fig. 1B) and studies focusing on specific countries were isolated efforts. It was not until after the 1960s when Belize, Panama and Costa Rica started to become more relevant, and continue to do so. The countries with the most scientific publications are Panama (134 studies), Belize (62) and Costa Rica (60), and the countries with the least contributions are Honduras (12), Nicaragua (9) and Guatemala (5).

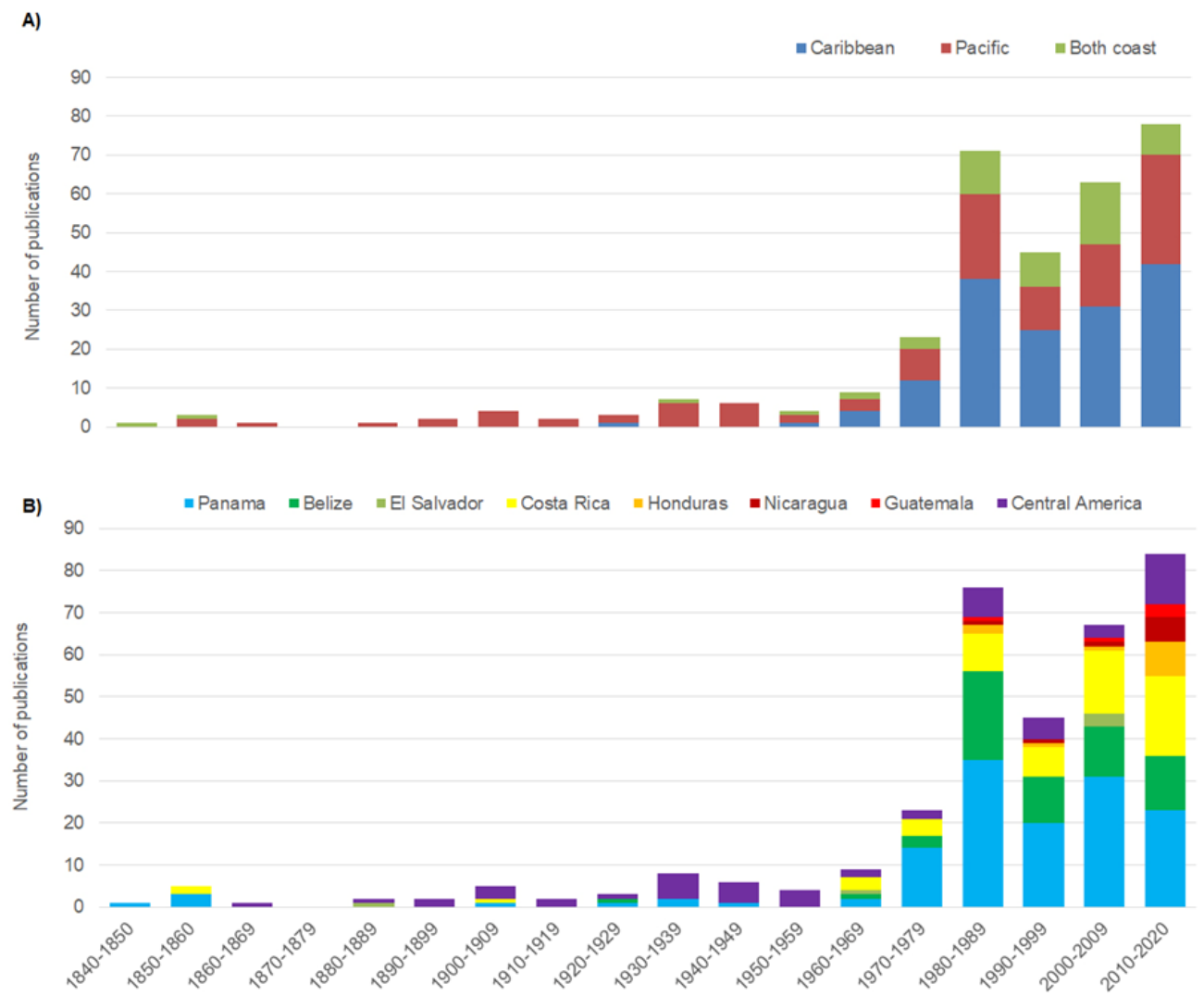

Fig. 1. Number of publications on echinoderms in Central America from 1840 to 2020, split into decades according to A) the coast on which these studies took place; and B) the countries in which these studies developed. 
The first echinoderm publication was written by J. E. Gray (1840) and focused on the Asteroidea class. Echinoidea has been the most researched class, with 122 studies overall and an average of 23 studies per decade between 1970 and 2020 (Fig. 2A). The other classes, Ophiuroidea, Holothuroidea and Asteroidea possess 47, 29 and 27 scientific studies, respectively. There are 82 studies focused on two or more classes. Crinoidea is the least studied class throughout the period analysed and is the subject of only 15 studies.

Before the 1970's, the focus of most published studies was taxonomy (38 publications). These were monographs and expedition reports that described species without further investigation of their ecology. Beginning in the 70's, the diversity of study organisms (Fig. 2A) and research topics (Fig. 2B) increased and shifted towards a focus on ecological topics. The research topic with the most publications since the 70's is ecology (141 publications), followed by evolution (45), diversity (37) and reproduction (27). The least studied topics are physiology (15 published studies), fisheries and management (9), parasitism (7) and environmental education (2).
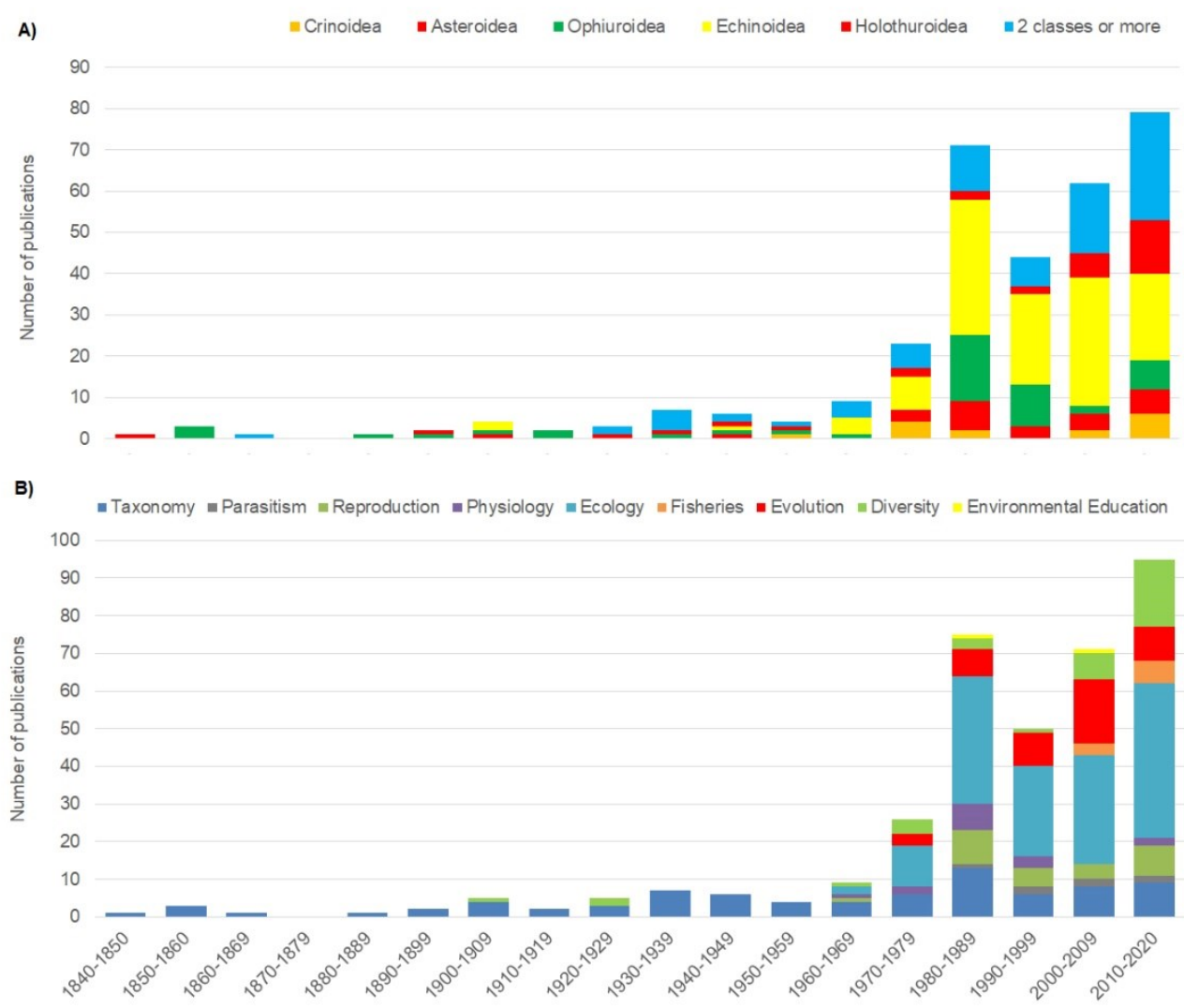

Fig. 2. Number of publications on echinoderms in Central America from 1840 to 2020, split into decades according to A) taxonomic class; and B) research topic.

Most published studies (80\%) were performed by foreign authors and Central American authors produced $12 \%$. Publications regarding echinoderms by local authors first appeared in the 1970's and have increased in number in the last two decades (2000-2020). There are few collaborative publications with foreign authors (8\%), though they have become more numerous in the last decade (Fig. 3A).

Publications were normally written under the name of a single author from the 1840 until the 1990's (Fig. 3B). The number of authors on each publication increased from the 1990's until the 
present. Of all studies considered, $46 \%$ were published under the name of a single author, $26 \%$ were published by two, $10 \%$ by three, $9 \%$ by four, $4 \%$ by five and $6 \%$ by six or more authors. If only the first or lead author is considered, a single author (Harilaos A. Lessios) composed more than 30 published works ( $0,7 \%$ of all studies considered) (Fig. 4). Most first authors (66,2\%) appear in only one publication and $28,2 \%$ appear in two to four publications. Overall, a total of 708 authors contributed to publications that met the search criteria and only $24,3 \%$ were female. Female authorship first appeared in 1938 (Deichmann, 1938) (Fig. 3C). In the 1980's the ratio of male to female authorship shrinks and female authors appear more frequently.

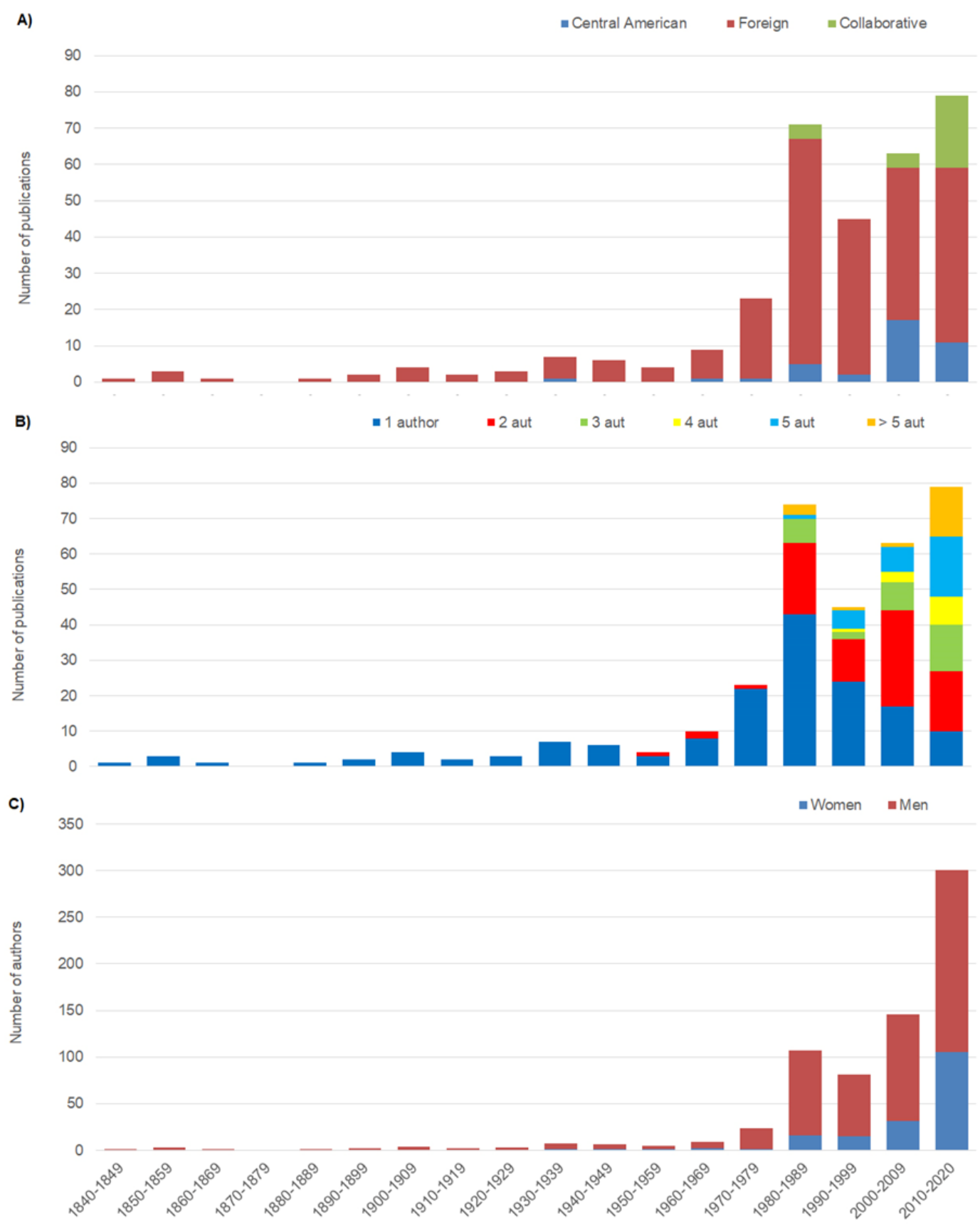

Fig. 3. Number of publications on echinoderms in Central America from 1860 to 2020, split into decades according to A) nationality of authors; B) number of authors per publication; and C) gender of authors in publications. 


\section{DISCUSSION}

From 1840 until 1980, echinoderm research was monopolized by foreign male researchers, mainly from Europe and the United States. This time period was focused mainly on the description of species collected during of scientific expeditions including the USS Albatross, Allan Hancock Foundation Velero III, SY Zaca, SY Arcturus, RV Stranger, RV Te Vega and the Rosaura Expedition (Alvarado et al., 2013; Coppard \& Lessios, 2017). Female participation in echinoderm studies has been lower than male, with a ratio of five male authors for each publication by a woman. These differences were even more pronounced during the first decades of echinoderm investigation. The presence of the renowned Danish scientist Elizabeth Deichmann stands out as the first woman to publish on echinoderm research in the region. She described, among other groups, several new echinoderm species and, thanks to her dedication, was one of the first women to be appointed Knight of Order of the Dannebrog by the King of Denmark (Levi, 1976; Ogilvie \& Harvey, 2000). Between the studies of Deichmann (Deichmann, 1938, 1941, 1958) and those of Susan Foster (Foster, 1987a, b), 29 years passed without a woman as the lead author of a published study. Female authors were always foreign to the region until Marta Valdez from Costa Rica, published a collaborative study as a first author (Valdez \& Villalobos, 1978). To date, no Central American woman has published as a sole author on a publication regarding echinoderms. Although female participation in publications in the region has been steadily increasing for the last decade, female authors are predominantly foreigners. This highlights the need for more integration of local women in these research projects.

Marine laboratories such as the Smithsonian Tropical Research Institute in Panama and Belize (Smithsonian Tropical Research Institute, 2021) were established during the 1970's and 1980 's. This contributed to publications dealing with a wider variety of research topics such as physiology, evolution, fisheries, among others. Additionally, the development of SCUBA diving technologies as a research tool not only catapulted the number of publications but also opened the new fields of research, such as ecology and physiology, which would have otherwise been challenging to carry out (Lang et al., 2013).

The class Echinoidea could be the topic of the most publications concerning echinoderms for several reasons. The relatively large sizes and the high abundance of sea urchins coupled with their easy observation and collection and the presence of marine laboratories were big factors. The presence of marine laboratories was a key factor in moving from only ecological or taxonomic work to more applied and specialized research, which only this type of facility can provide. On the other hand, since the isthmus is relatively young geologically (approximately 3,5 million years) (O'Dea et al., 2016), sea urchins have been used in numerous evolutionary studies (Lessios, 1979, 1981a, 1990; Lessios \& Cunningham, 1990; Bermingham \& Lessios, 1993; Lessios et al., 1998, 1999; 2003, Coppard \& Lessios, 2017, among others). The genus Diadema is responsible for many Echinoidea studies in both coasts. The mass mortality of $D$. antillarum that occurred in the Caribbean during the 1980's (Lessios et al., 1984) gave rise to a great number of studies focusing on understanding the causes and ecological impact of the genus on coral reefs (Valdez \& Villalobos, 1978; Lessios, 1981b, 1985, 1988, 2016; Murillo \& Cortés, 1984; Foster, 1987a, Alvarado et al., 2004; Myhre \& AcevedoGutiérrez, 2007; Bodmer et al., 2015; Cramer et al., 2017). On the Pacific coast, the genus Diadema also contributes to a high number of publications that mainly focus on the impact of $D$. mexicanum population outbreaks on coral reefs and carbonate budgets linked to El Niño events (Glynn, 1985, 1988; Eakin, 1992, 1996, 2001; Alvarado et al., 2012, 2016).

The few publications on Crinoidea, the least studied class, are focused on shallow reef species in the Caribbean coast of Honduras and Belize (Meyer et al., 1978; Marcuda, 1982; Syverson et al., 2015). On the Pacific side, crinoid species are primarily found in deep waters (Alvarado et al., 
2013) which has made their study a difficult feat since it requires the use of remotely operated underwater vehicles (ROV's) and submarines. Recent studies have been carried out on the Pacific coast of Costa Rica that aim to investigate deep sea environments and contribute to a deeper understanding of this class (Levin et al., 2012, 2015).

The relative political stability in the last 20 years has favoured the development of universities and local research centres and a corresponding greater presence of local researchers. Nonetheless, much more remains to be done to promote the strength and collaboration of marine sciences. Scientific collaboration between researchers, institutions and countries has been proven to be a valuable tool that contributes to scientific progress (Newman, 2001; Nieto \& Santamaría, 2007; García-Hernández, 2013). Collaboration facilitates the sharing of knowledge, economic and material resources, which otherwise not be available. Concrete results of scientific collaboration networks are co-authorships of scientific papers and may also include participation in thesis committees, courses, seminars, and internships. In the last two decades, these networks are flourishing with technological progress in communication and scientific advancement in developing countries (Radicchi et al., 2004; Gazni et al., 2012). The Iberoamerican Echinoderm Network (Red Iberoamericana de Equinodermos, 2021), founded in 2006, has facilitated collaboration between researchers and peers in Mexico, Spain, Colombia, Brazil, Uruguay, Ecuador and Argentina (Alvarado \& Cortés, 2005, 2008; Alvarado \& Solís-Marín, 2013, 2015; Rubilar et al., 2017). Although there has been notable progress, much remains to be done to improve gender equality and local participation among the Central American scientific community.

The region is classified as an intense illegal fishing site for sea cucumbers (Holothuroidea). There are few protection measures and many signs of overexploitation (Purcell et al., 2013) that indicate the urgency to assume management and conservation measures for the resource. This apparent and pressing need contrasts with the small number of published studies focusing on fisheries and their management (only $2,8 \%$ of studies found). Because only $9,1 \%$ of considered studies focus on sea cucumbers, more knowledge is needed to preserve the echinoderms as a resource. It is vital to conduct baseline studies of the population dynamics, genetic connectivity, and physiology and reproduction of these organisms. Additionally, these studies must go hand in hand with research that educates, creates and raises awareness, and provides innovative, sustainable alternatives and collaboration with the private sector. It is crucial to start developing new fields of research that focus on aquaculture, fisheries, environmental education, conservation, and management of shallow-water echinoderms, and to continue expanding our current knowledge of deep-sea groups in order to make the most of the valuable trajectory that has been developing over the 180 years of scientific research in the region.

\section{ACKNOWLEDGEMENTS}

We thank colleagues and librarians who have helped us to compile literature related to this group of organisms, especially Jorge Cortés and Francisco Alonso Solís Marín. This manuscript was improved through the comments from Jorge Cortés, Odalisca Breedy, Sergio Madrigal-Mora, Benjamin Chomitz and two anonymous reviewers, to whom we are very thankful. 


\section{ETHICAL, CONFLICT OF INTEREST AND FINANCIAL STATEMENTS}

The authors declare that they have fully complied with all pertinent ethical and legal requirements, both during the study and in the production of the manuscript; that there are no conflicts of interest of any kind; that all financial sources are fully and clearly stated in the acknowledgements section; and that they fully agree with the final edited version of the article. A signed document has been filed in the journal archives.

J.J.A.: Study design, data collection and analysis. S.F.M.: Data collection. All co-authors: preparation and final approval of the manuscript.

\section{REFERENCES}

Alvarado, J. J., Baraza, E., \& Sancho-Mejía, T. (2013). Central America Echinoderms: diversity, ecology, and future perspectives. In J.J. Alvarado \& F.A. Solís-Marín (Eds.), Echinoderm research and diversity in Latin America (pp. 67-106). Springer.

Alvarado, J. J., \& Cortés, J. (2005). Research on Echinoderms in Latin America. Revista de Biología Tropical, 53(Suppl. 3). 1404. https://doi.org/10.15517/rbt.v65i1-1

Alvarado, J. J., \& Cortés, J. (2008). Research on Echinoderms in Latin America II. Revista de Biología Tropical, 56(Suppl. 3). 1-360. https://doi.org/10.15517/rbt.v56i3

Alvarado, J. J., Cortés, J., Guzmán, H. M., \& Reyes-Bonilla, H. (2016). Bioerosion by the sea urchin Diadema mexicanum along Eastern Tropical Pacific coral reef. Marine Ecology, 37(5), 1088-1102. https://doi.org/10.1111/maec.12372

Alvarado, J. J., Cortés, J., \& Salas, E. (2004). Population Densities of Diadema antillarum Philippi (Echinodermata: Echinoidea) at Cahuita National Park (1977-2003), Costa Rica. Caribbean Journal of Science, 40(2), 257-259.

Alvarado, J. J., Cortés, J., \& Reyes-Bonilla, H. (2012). Reconstruction of Diadema mexicanum A. Agassiz, 1863 bioerosion impact on three Costa Rican Pacific coral reefs. Revista de Biología Tropical, 60(Suppl. 2), 121-132. https://doi.org/10.15517/rbt.v60i2.19975

Alvarado, J. J., \& Solís-Marín, F. A. (2013). Echinoderm Research and Diversity in Latin America. Springer.

Alvarado, J. J., \& Solís-Marín, F. A. (2015). Research on Echinoderms in Latin America III. Revista de Biología Tropical, 63(Suppl. 2), 1-381. https://doi.org/10.15517/rbt.v63i2

Bermingham, E., \& Lessios, H. A. (1993). Rate variation of protein and mitochondrial DNA evolution as revealed by sea urchins separated by the Isthmus of Panama. Proceedings of the National Academy of Sciences of the United States of America, 90, 2734-2738. https://doi.org/10.1073/pnas.90.7.2734

Biodiversity Heritage Library (2021). Biodiversity Heritage Library Homepage. https://www.biodiversitylibrary.org/

Bodmer, M. D. V., Rogers, A. D., Speight, M. R., Lubbock, N., \& Exton, D. A. (2015). Using an isolated population boom to explore barriers to recovery in the keystone Caribbean coral reef herbivore Diadema antillarum. Coral Reefs, 34, 1011-1021. https://doi.org/10.1007/s00338-015-1329-4

Cambronero-Solano, S., Benavides, R., Solís-Marín, F. A., \& Alvarado, J. J. (2019). New reports of echinoderms on the Caribbean Continental Shelf of Central America. Zoosymposia, 15(1), 5-12. https://doi.org/10.11646/zoosymposia.15.1.3

Coppard, S., \& Alvarado, J. J. (2013). Echinoderm diversity in Panama: 144 years of research across the isthmus. In J.J. Alvarado., \& F.A. Solís-Marín (Eds.), Echinoderm research and diversity in Latin America (pp. 107-144). Springer. 
Coppard, S. E., \& Lessios, H. A. (2017). Phylogeography of the sand dollar genus Encope: implications regarding the Central American Isthmus and rates of molecular evolution. Scientific Reports, 11520. https://doi.org/10.1038/s41598017-11875-w

Cortés, J. (2007). Coastal morphology and coral reefs. In J. Bundschuh., \& G. E. Alvarado (Eds.), Central America: geology, resources, and hazards (pp. 185-200). Taylor \& Francis.

Cramer, K. L., O'Dea, A., Carpenter, C., \& Norris, R. D. (2017). A 3000-year record of Caribbean reef urchin communities reveals causes and consequences of long-term decline in Diadema antillarum. Ecography, 41, 164-173, https://doi.org/10.1111/ecog.02513

Deichmann, E. (1938). Holothurians from the western coast of Lower California and Central America, and from the Galápagos Islands; Eastern Pacific Expeditions of the New York Zoological Society XVI. Zoologica, 23, 361-187.

Deichmann, E. (1941). The Holothuroidea collected by the Velero III during the years 1932 to 1938 . Part I, Dendrochirota. Allan Hancock Pacific Expeditions, 8, 61-194.

Deichmann, E. (1958). The Holothuroidea collected by the Velero II and IV during the years 1932 to 1954. Part II. Aspidochirota. Allan Hancock Pacific Expeditions, 11, 253-349.

Eakin, C. M. (1992). Post-El Niño Panamanian reefs: less accretion, more erosion and damselfish protection. Proceedings of the 7th International Coral Reef Symposium (pp. 387-396). Guam, Micronesia.

Eakin, C. M. (1996). Where have all the carbonates gone? A model comparison of calcium carbonate budgets before and after the 1982-1983 El Niño at Uva Island in the Eastern Pacific. Coral Reefs, 15, 109-119. https://doi.org/10.1007/bf01771900

Eakin, C. M. (2001). A tale of two ENSO events: carbonate budgets and the influence of two warming disturbances and intervening variability, Uva Island, Panama. Bulletin of Marine Science, 69, 171-186.

Foster, S. A. (1987a). The relative impacts of grazing by Caribbean coral reef fishes and Diadema: effects of habitat and surge. Journal of Experimental Marine Biology and Ecology, 105, 1-20. https:// doi.org/10.1016/S00220981(87)80026-6

Foster, S. A. (1987b). Territoriality of the dusky damselfish: influence on algal biomass and on the relative impacts of grazing by fishes and Diadema. Oikos, 50, 153-160. https://doi.org/10.2307/3565995

García-Hernández, A. (2013). Las redes de colaboración científica y su efecto en la productividad. Un análisis bibliométrico. Investigación bibliotecológica, 27, 159-175. https://doi.org/10.1016/S0187-358x(13)72535-8

Gazni, A., Sugimoto, C. R., \& Didegah, F. (2012). Mapping world scientific collaboration: Authors, institutions, and countries. Journal of the American Society for Information Science and Technology, 63(2), 323-335. https://doi.org/10.1002/asi.21688

Glynn, P. W. (1985). Corallivore population size and feeding effects following El Niño (1982-83) associated coral mortality in Panama. Proceedings of the 5th International Coral Reef Symposium (pp. 183-188). Tahiti, French Polynesia.

Glynn, P. W. (1988). El Niño warming, coral mortality and reef framework destruction by echinoid bioerosion in the eastern Pacific. Galaxea, 7, 129-160.

Gray, J. E. (1840). A synopsis of the genera and species of the class Hypostoma (Asterias Linn.). Annals and Magazine of Natural History series 1, 6, 175-184.

Lang, M. A., Marinelli, R. L., Roberts, S. J., \& Taylor, P. R. (2013). Research and Discoveries: The Revolution of Science through Scuba. Smithsonian Contributions to the Marine Sciences, 39, 1-258.

Lessios, H. A. (1979). Use of Panamanian sea urchins to test the molecular clock. Nature, 280, $599-601$. https://doi.org/10.1038/280599a0 
Lessios, H. A. (1981a). Divergence in allopatry: molecular and morphological differentiation between sea urchins separated by the Isthmus of Panama. Evolution, 35, 618-634. https://doi.org/10.2307/2408235

Lessios, H. A. (1981b). Reproductive periodicity of the echinoid Diadema and Echinometra on the two coasts of Panama. Journal of Experimental Marine Biology and Ecology, 50, 47-61. https://doi.org/10.1016/0022-0981(81)90062-9

Lessios, H. A. (1985). Genetic consequences of mass mortality in the Caribbean sea urchin Diadema antillarum. Proceedings of the 5th International Coral Reef Congress (pp. 371-393). Tahiti, French Polynesia.

Lessios, H. A. (1988). Populations dynamics of Diadema antillarum (Echinodermata: Echinoidea) following mass mortality in Panama. Marine Biology, 99, 515-526. https://doi.org/10.1007/BF00392559

Lessios, H. A. (1990). Adaptation and phylogeny as determinants of egg size in echinoderms from the two sides of the Isthmus of Panama. The American Naturalist, 135, 1-13. https://doi.org/10.1086/285028

Lessios, H. A. (2016). The Great Diadema antillarum Die-Off: 30 Years Later. Annual Review of Marine Science, 8, $267-283$. https://doi.org/10.1146/annurev-marine-122414-033857

Lessios, H. A., \& Cunningham, C. W. (1990). Gametic incompatibility between species of the sea urchin Echinometra on the two sides of the Isthmus of Panama. Evolution, 44, 933-941, https://doi.org/10.1111/i.15585646.1990.tb03815.x

Lessios, H. A., Kane, J., \& Robertson, D. R. (2003). Phylogeography of the pantropical sea urchin Tripneustes: contrasting patterns of population structure between oceans. Evolution, 57, 2026-2036. https://doi.org/10.1111/j.00143820.2003.tb00382.x

Lessios, H. A., Kessing, B. D., \& Robertson, D. R. (1998). Massive gene flow across the world's most potent marine biogeographic barrier. Proceedings of the Royal Society B, 265, 583-588. https://doi.org/10.1098/rspb.1998.0334

Lessios, H. A., Kessing, B. D., \& Robertson, D. R. (1999). Phylogeography of the pantropical sea urchin Eucidaris in relation to land barriers and ocean currents. Evolution, 53, 806-817.

Lessios, H. A., Robertson, D. R., \& Cubit, J. D. (1984). Spread of Diadema mass mortality through the Caribbean. Science, 226, 335-337, https://doi.org/10.1126/science.226.4672.335

Levi, H. W. (1976). In Memoriam: Elisabeth Deichmann (1896-1975). Bulletin of Marine Science, 26, 281-283.

Levin, L. A., Mendoza, G.F., Grupe, B. M., Gonzalez, J. P., Jellison, P., Rouse, G., Thurber, A. R., \& Waren, A. (2015). Biodiversity on the rocks: Macrofauna inhabiting authigenic carbonate at Costa Rica methane seeps. PLoS ONE, 10(7). https://doi.org/10.1371/journal.pone.0131080

Levin, L. A., Orphan, V. J., Rouse, G. W., Rathburn, A. E., Ussler, W., Cook, G. S., Goffredi, S. K., Perez, E. M., Waren, A., Grupe, B. M., Chadwick, G., \& Strickrott, B. (2012). A hydrothermal seep on the Costa Rican margin: Middle ground in a continuum of reducing ecosystems. Proceedings of the Royal Society B: Biological Sciences, 279(1738), 2580-2588. https://doi.org/10.1098/rspb.2012.0205

Macurda, D. B. (1982). Shallow-water Crinoidea (Echinodermata) from Carrie Bow, Belize. In K. Rützler, \& I.G. Macintyre (Eds.), The Atlantic Barrier Reef Ecosystem at Carrie Bow Cay, Belize, I: Structure and Communities (pp. 413-416). Smithsonian Institution Press.

Meyer, D. L., Messing, C. G., \& Macurda, D. B. (1978). Zoogeography of Tropical Western Atlantic Crinoidea (Echinodermata). Bulletin of Marine Science, 28(3), 412-441.

Murillo, M. M., \& Cortés, J. (1984). Alta mortalidad en la poblacion del erizo de mar Diadema antillarum Philippi (Echinodermata: Echinoidea), en el Parque Nacional Cahuita, Limón, Costa Rica. Revista de Biología Tropical, 32, 167-169. 
Myhre, S., \& Acevedo-Gutiérrez, A. (2007). Recovery of sea urchins Diadema antillarum populations is correlated to increased coral and reduced macroalgal cover. Marine Ecology Progress Series, 329, 205-210. https://doi.org/10.3354/meps329205

Newman, M. E. J. (2001). The structure of scientific collaboration networks. Proceedings of the National Academy of Sciences of the United States of America, 98, 404-409. https://doi:10.1073/pnas.98.2.404

Nieto, M. J., \& Santamaría, L. (2007). The importance of diverse collaborative networks for the novelty of product innovation. Technovation, 27, 367-377. https://doi.org/10.1016/j.technovation.2006.10.001

O’Dea, A., Lessios, H. A., Coates, A. G., Eytan, R. I., Restrepo-Moreno, S. A., Cione, A. L., Collins, L. S., de Queiroiz, A., Farris, D. W., Norris, R. D., Stallard, R. F., Woodburne, M. O., Aguilera, O., Aubry, M. P., Berggren, W. A., Budd, A. F., Cozzuol, M. A., Coppard, S. E., Duque-Caro, H., Finnegan, S., Gasparini, G. M., Grossman, E. L., Johnson, K. G., Keigwin, L. D., Knowlton, N., Leigh, E. G., Leonard-Pingel, J. S., Marko, P. B., Pyenson, N. D., Rachello-Dolmen, P. G., Soibelzon, E., Sobeilzon, L., Todd, J. A., Vermeij, G. J., \& Jackson, J. B. C. (2016). Formation of the Isthmus of Panama. Science Advances, 2(8), e1600883. https://doi.org/10.1126/sciadv.1600883

O'Hara, T. D., \& Byrne, M. (2017). Ecology and Behaviour. In M. Byrne \& T.D. O'Hara (Eds.), Australian Echinoderms: Biology, Ecology \& Evolution (pp. 37-74). CSIRO Publishing.

Ogilvie, M., \& Harvey, J. (2000). The biographical dictionary of women in science: Pioneering lives from ancient times to the mid-20th century. Routledge.

Pawson, D. L. (2007). Phylum Echinodermata. Zootaxa, 1668, 749-764.

Purcell, S. W., Mercier, A., Conand, C., Hamel, J. F., Toral-Granda, M. V., Lovatelli A., \& Uthicke, S. (2013). Sea cucumber fisheries: Global analysis of stocks, management measures and drivers of overfishing. Fish and Fisheries, 14, 3459. https://doi.org/10.1111/j.1467-2979.2011.00443.x

Radicchi, F., Castellano, C., Cecconi, F., Loreto, V., \& Parisi, D. (2004). Defining and identifying communities in networks. Proceedings of the National Academy of Sciences of the United States of America, 101, 2658-2663. https://doi.org/10.1073/pnas.0400054101

Red Iberoamericana de Equinodermos. (2021). https://rediberoamericanaequinodermos.com

Rubilar, T., Alvarado, J. J., \& Salas-Moya, C. (2017). Research on Echinoderms in Latin America IV. Revista de Biología Tropical, 65 (Suppl. 1), 1-308.

Smithsonian Tropical Research Institute (2021). Smithsonian Institution Archives: History: https://siarchives.si.edu/history/smithsonian-tropical-research-institute.

Syverson, V. J., Messing, C. G., Stanley, K., \& Baumiller, T. K. (2015). Growth, injury, and population dynamics in the extant cyrtocrinid Holopus mikihe (Crinoidea, Echinodermata) near Roatán, Honduras. Bulletin of Marine Science, 91(1), 47-61. https://doi.org/10.5343/bms.2014.1061

Valdez, M. F., \& Villalobos, C. R. (1978). Distribución espacial, correlación con el sustrato y grado de agregación en Diadema antillarum Phillipi (Echinodermata: Echinoidea). Revista de Biología Tropical, 26, 237-245. 


\section{SUPPLEMENTARY MATERIAL}

TABLE S1

Chronological list of contributions of echinoderms in Central America.

\section{Contribution}

Gray, J.E. (1840). A synopsis of the genera and species of the class Hypostoma (Asterias Linn.). Annals and Magazine of Natural History series 1, 6, 175-184.

Le Conte, J.L. (1851). Zoological Notes. Proceedings of the Society of Natural History Philadelphia 1850-1851, 5, 316-319

Lütken, C. F. (1856). Bidrag til kundskab om Slangestjernerne. III Bidrag til kundskab om ophiurere ved Central Amerikas Vestkyst. Videnskabelige Meddelelser fra Dansk Naturhistorisk Förening i Kjøbenhavn 7,20-26.

Lütken, C.F. (1859). Additamenta ad historiam Ophiuridarum. Tredie Afsnit. Beskrivelse af de fra Vestindien of CentralAmerikas Vestkyst hidril bekjendte Slangestjerner. B. Lunos bogtrykkeri ved F.S. Muhle, Kjøbenhavn, Ser 5(5), 174275.

Verrill, A.E. (1867). Notes on the echinoderms of Panama and west coast of America, with description of new genera and species. Trans. Connect. Acad. Arts Sci., 1(2), 251-322.

Lyman, T. (1882). Report on the Ophiuroidea dredged by H.M.S. "Challenger" during the years 1873-1876. Report of the Scientific Results of the Voyage of H.M.S. "Challenger" 1873-1876, 5(14), 1-386.

Ludwig, H. (1894). Reports on an exploration off the west coast of Mexico, Central America and South America, and off the Galápagos Islands, in charge of Alexander Agassiz, by the U.S. Fish Commission steamer "Albatross", during 1891. XII. The Holothuroidea. Mem. Mus. Comp. Zool., 17(3), 1-183.

Lütken, C.F., Mortensen, T. (1899). Reports on an exploration off the west coast of Mexico, Central America and South America, and off the Galápagos Islands, in charge of A. Agassiz, during 1891 on the "Albatross". XXV. The Ophiuroidea. Mem. Mus. Comp. Zool., 23(2), 93-208.

Agassiz, A. (1904). Reports on an exploration off the west coast of Mexico, Central and south America, and off Galapagos Islands, in charge of Alexander Agassiz, by the U.S. Fish Commission Steamer "Albatross", during 1891, Lieut. Commander Z.L. Tanner, U.S. Commanding. XXXII. The Panamic deep sea echini. Mem. Mus. Zool. Harvard Coll., $31,1-246$.

Agassiz, A. (1904). The Panamic deep sea Echini. Mem. Mus. Zool. Harvard Coll., 31, 1-243.

Ludwig, H. (1905). Asteroidea in: Explorations of "Albatross" in Tropical Pacific, 1891 and 1899-1900. Mem. Mus. Comp. Zool., 22(7), 1-290.

Koehler, R. (1907). Revision de la Collection des Ophiures du Museum D’Historie Naturelle de Paris. Bulletin Scientifique de la France et de la Belgique 61, 279-370.

Clark, H.L. (1915). Catalogue of recent ophiurans: Based on the collection of the Museum of Comparative Zoölogy. Memoirs of the Museum of Comparative Zoology, 25(4), 164-376.

Clark, H.L. (1917). Reports on the scientific results of the expedition to the tropical Pacific in charge of Alexander Agassiz, on the U.S. Fish Commission Steamer "Albatross" from August 1899 to March 1900, commander Jefferson F. Mooser, U.S.N Commanding. XVIII. Reports on the scientific results of the expedition to the tropical Pacific in charge of Alexander Agassiz, on the U.S. Fish Commission Steamer "Albatross" from October 1904 to March 1905, Lieut. Commander L.M. Garret, U.S.N. Commanding. Bull. Mus. Comp. Zool. Harvard Coll., 61, 429-466.

Boone, L. (1928). Scientific results of the first oceanographic expedition of the Pawnee 1925. Echinodermata from tropical east American seas. Bulletin of the Bingham Oceanographic collection, 1, 1-22.

Boone, L. (1928). Echinoderms from the Gulf of California and the Perlas Islands. Bulletin of the Bingham Oceanographic collection, 2, 1-14. 
Fisher, W.K. (1928). Sea stars from the Arcturus oceanographic expedition. Zoologica, 8, 487-493.

Clark, A.H. (1931). A monograph of existing crinoids. Bull. US. Nat. Mus., 82(1), 1-186.

Nielsen, (1932). E. Papers from Dr. Th. Motensen's Pacific Expedition 1914-16 LIX. Ophiurians from the Gulf of Panama, California and the Strait of Georgia. Videnskabelige Meddelelser Dansk Naturhistorisk Forening, 91, 280-295.

Boone, L. (1933). Scientific results of cruises of the yachts "Eagle" and "Ara", 1921-1928, William K. Vanderbilt, commanding. Coelenterata, Echinodermata and Mollusca. Bulletin of the Vanderbilt Marine Museum, 4, 1-217.

Ziesenhenne, F.C. (1937). The Templeton Crocker Expedition. X. Echinoderms from the West coast of Lower California, the Gulf of California and Clarion Island. Zoologica, 22, 209-239.

Deichmann, E. (1938). Holothurians from the western coast of Lower California and Central America, and from the Galápagos Islands; Eastern Pacific Expeditions of the New York Zoological Society XVI. Zoologica, 23, 361-187.

Clark, A.H. (1939). Echinoderms (other than Holothurians) collected on the Presidential Cruise of 1938. Smithson. Miscell. Collec., 98(11), 1-22.

Clark, H.L. (1940). Eastern Pacific Expeditions of the New York Zoological Society. XXI. Notes on Echinoderms from the west coast of Central America. Zoologica, 25, 331-352.

Ziesenhenne, F.C. (1940). New ophiurans of the Allan Hancock Pacific Expeditions. Allan Hancock Pac. Exped., 8(2), 959.

Deichmann, E. (1941). The Holothuroidea collected by the Velero III during the years 1932 to 1938. Part I, Dendrochirota. Allan Hancock Pac. Exped., 8, 61-194.

Ziesenhenne, F.C. (1942). New eastern Pacific sea stars. Allan Hancock Pac. Exped., 8(4), 197-223.

Clark, A.H. (1946). Echinoderms from the Pearl Islands, Bay of Panama, with a revision of the Pacific species of the genus Encope. Smithson. Miscell. Collec., 106(5), 1-11.

Clark, H.L. (1948). A report on the Echini of the warmer eastern Pacific, based on the collections of the Velero III. Allan Hancock Pac. Exped., 8(5), 225-352.

Clark, A.H. (1950). A monograph of the existing crinoids. Vol 1, The Comatulids. Part 4c. Superfamily Tropometrida (The families Thalassometridae and Charitometridae). U.S. Nat. Mus. Bull., 82, 1-382.

John, D.D., \& Clark, A.M. (1954). The "Rosaura" Expedition 1937-1938. 3. The Echinodermata. Bull. Hr. Mus. Nat. Hist. (Zool.), 2, 139-162.

Ziesenhenne, F.C. (1955). A review of the genus Ophioderma. In Allan Hancock Foundation (Eds.), Essays in the Natural Sciences in Honor of Captain Allan Hancock on the Occasion of his Birthday, July 26, 1955 (pp. 185-201). University of Southern California Press.

Deichmann, E. (1958). The Holothuroidea collected by the Velero II and IV during the years 1932 to 1954 . Part II. Aspidochirota. Allan Hancock Pac. Exped., 11, 253-349.

Aberson, V.T., \& Engel, H. (1960). Uber einige echinodermen von El Salvador (C-Amerika) und von den Farallon-Inseln (Kalifornien). Senckenbergiana Biologica, 41, 363-366.

Stoddard, D.R. (1962). Three Caribbean Atolls: Turneffe Islands, Lighthouse Reef, and Glover's Reef, British Honduras. Atoll Res. Bull., 87, 1-151.

Hertlein, L.G. (1963). Contribution to the biogeography of Cocos Island, including a bibliography. Proc. Cal. Acad. Sci., $32,123-235$.

Lawrence, J.M. (1967). Lipid reserves in the gut of three species of tropical sea urchins. Caribb. J. Sci., 7(1-2), 65-68.

Chesher, R.H. (1968). Lytechinus williamsi, a new sea urchin from Panama. Breviora, Museum of Comparative Zoology, 305, 1-13. 
Downey, M.E. (1968). Catalogue of Recent Echinoid Type Specimens in the U.S. National Museum Smithsonian Institution and the Museum of Comparative Zoology Harvard University. United States National Museum Bulletin 264, v-vi, 1-99.

Pearse, J.S. (1968). Gametogenesis and reproduction in several abyssal and shallow water echinoderms of the Eastern Tropical Pacific. Stanford Oceanogr. Exp. Cruise 20 Te Vega Rep., 225-234.

Chesher, R.H. (1969). Contributions to the biology of Meoma ventricosa (Echinoidea: Spatangoida). Bull. Mar. Sci., 19, 73-110.

Downey, M.E. (1969). Catalog of recent ophiuroid type specimens in major collections in the United States. United States National Museum Bulletin, 293, 1-239.

Chesher, R.H. (1970). Evolution in the genus Meoma (Echinoidea: Spatangoida) and a description of a new species from Panama. Biological Results of The University Of Miami Deep-Sea Expeditions, 68, 20, 731-761.

Chesher, R.H. (1972). The status of knowledge of Panamanian Echinoids, 1971, with comments on other Echinoderms. Bull. Biol. Soc. Wash., 2, 139-157.

Meyer, D.L. (1972). Ctenantedon, a new antedonid crinoid convergent with comasterids. Bull. Mar. Sci., 22(1), 53-66.

Glynn, P.W. (1973). Acanthaster: Effect on coral reef growth in Panama. Science, 180, 504-506.

Meyer, D.L. (1973). Feeding behavior and ecology of shallow-water unstalked crinoids (Echinodermata) in the Caribbean Sea. Mar. Biol., 22, 105-129.

Bakus, G.J. (1974). Toxicity in holothurians: a geographical pattern. Biotropica, 6, 229-236.

Devaney, D.M. (1974). Shallow-water echinoderms from British Honduras, with a description of a new species of Ophiocoma (Ophiuroidea). Bull. Mar. Sci., 24, 122-164.

Glynn, P.W. (1974). The impact of Acanthaster on corals and coral reefs in the eastern Pacific. Environ. Conserv., 1, 295304.

Wellington, G.M. (1974). An ecological description of the marine and associated environments at Monumento Nacional Cahuita; Subdirección de Parques Nacionales, Ministerio de Agricultura y Ganadería, Costa Rica.

Bakus, G.J. (1975). Marine zonation and ecology of Cocos Island, off Central America. Atoll Res. Bull., 179, 1-11.

Kier, P.M. (1975). The echinoids of Carrie Bow Cay, Belize. Smithsonian Contr. Zool., 206, 1-20.

Glynn, P.W. (1976). Some physical and biological determinants of coral community structure in the Eastern Pacific. Ecol. Monogr., 46, 431-456.

Pawson, D.L. (1976). Shallow-water sea cucumbers (Echinodermata: Holothuroidea) from Carrie Bow Cay, Belize. Proc. Biol. Soc. Wash., 89, 369-382.

Dexter, D. (1977). A natural history of the sand dollar Encope stokesi L. Agassiz in Panama. Bull. Mar. Sci., 27(3), 544551.

Glynn, P.W. (1977). Interactions between Acanthaster and Hymenocera in the field and laboratory. Proceedings of the 3rd International Coral Reef Symposium (pp. 209-215). Ft. Lauderdale, FL, USA.

Heck, K.L. Jr. (1977). Comparative species richness, composition, and abundance of invertebrates in Caribbean seagrass (Thalassia testudinum) meadows (Panamá). Mar. Biol., 41, 335-348.

Hendler, G. (1977). The differential effects of seasonal stress and predation on the stability of reef-flat echinoid populations. Proceedings of the 3rd International Coral Reef Symposium (pp. 217-223). Ft. Lauderdale, FL, USA.

Meyer, D.L., Messing, C.G., \& Macurda, D.B. (1978). Zoogeography of Tropical Western Atlantic Crinoidea (Echinodermata). Bull. Mar. Sci., 28, 412-441. 
Valdez, M.F., \& Villalobos, C.R. (1978). Distribución espacial, correlación con el substrato y grado de agregación en Diadema antillarum Phillipi (Echinodermata: Echinoidea). Rev. Biol. Trop., 26, 237-245.

Lessios, H.A. (1979). Use of Panamanian sea urchins to test the molecular clock. Nature, 280, 599-601.

Lessios, H.A. (1979). Molecular, Morphological and Ecological Divergence of Shallow-water Sea Urchins Separated by the Isthmus of Panama [Ph.D. Dissertation, Yale University].

Seilacher, A. (1979). Constructional morphology of sand dollars. Paleobiology, 5, 191-221.

Fischer, R. (1981). Bioerosion of basalt of the Pacific coast of Costa Rica. Senckenbergiana maritima, 13, 1-41.

Glynn, P.W. (1981). Acanthaster population regulation by a shrimp and a worm. Proceedings of the 4th International Coral Reef Symposium (pp. 607-612). Manila, Philippines.

Lessios, H.A. (1981). Evidencia preliminar de una duplicación del gen en la evolución de la clase Echinoidea. Academia Panameña de Medicina y Cirugía, 6(1), 46-55.

Lessios, H.A. (1981). Divergence in allopatry: molecular and morphological differential between sea urchins separated by the Isthmus of Panama. Evolution, 35, 618-634.

Lessios, H.A. (1981). Reproductive periodicity of the echinoid Diadema and Echinometra on the two coasts of Panama. J. Exp. Mar. Biol. Ecol., 50, 47-61.

Scheibling R.E. (1981). The annual reproductive cycle of Oreaster reticulatus (L.) (Echinodermata: Asteroidea) and interpopulation differences in reproductive capacity. J. Exp. Mar. Biol. Ecol., 54, 39-54.

Strathmann, R.R. (1981). The role of spines in preventing structural damage to echinoids tests. Paleobiology, 7, $400-406$.

Glynn, P.W. (1982). Individual recognition and phenotypic variability in Acanthaster planci (Echinodermata: Asteroidea). Coral Reefs, 1, 89-94.

Glynn, P.W., Von Prahl, H., \& Guhl, F. (1982). Coral reefs of Gorgona Island, with special reference to corallivores and their influence on community structure and reef development. A. Inst Inv. Mar. Punta Betin, 12, 185-214.

Hendler, G. (1982). Slow flicks show star tricks: elapsed-time analysis of basketstar (Astrophyton muricatum) feeding behavior. Bull. Mar. Sci., 32(4), 909-918.

Hendler, G. (1982). An echinoderm vitellaria with a bilateral larval skeleton: evidence for the evolution of ophiuroid vitellariae from ophioplutei. Biol. Bull., 163, 431-437.

Hendler, G., \& Meyer, D.L. (1982). An association of a polychaete, Branchiosyllis exilis with an ophiuroid, Ophiocoma echinata, in Panama. Bull. Mar. Sci., 32, 736-744.

Hotchkiss, F.H.C. (1982). Ophiuroidea (Echinodermata) from Carrie Bow Cay, Belize. In K. Rützler, \& I.G. Macintyre (Eds.), The Atlantic Barrier Reef Ecosystem at Carrie Bow Cay, Belize, I: Structure and Communities (pp. 387-411). Smithsonian Institution Press.

Luke, S.R. (1982). Catalog of benthic invertebrate collections, Echinodermata. Scripps Institution of Oceanography series, no.82-5. University of California. $66 \mathrm{p}$.

Macurda, D.B. (1982). Shallow-water Crinoidea (Echinodermata) from Carrie Bow, Belize. In K. Rützler., \& I.G. Macintyre (Eds.), The Atlantic Barrier Reef Ecosystem at Carrie Bow Cay, Belize, I: Structure and Communities (pp. 413-416). Smithsonian Institution Press.

Vadas, R.L., Fenchel, T., \& Ogden, J.C. (1982). Ecological studies on the sea urchin, Lytechinus variegatus, and the algalseagrass communities of the Miskito Cays, Nicaragua. Aquat. Bot., 14, 109-125.

Villalobos-Solé, C. (1982). Animales y plantas comunes de las costas de Costa Rica. Editorial Universidad Estatal a Distancia. 
Hay, M.E., Colbum, T., \& Downing, D. (1983). Spatial and temporal patterns in herbivory on a Caribbean fringing reef: the effects on plant distribution Oecologia, 58, 299-308.

Lessios, H.A. (1983). Los erizos de mar panameños, las lesiones que causan y su tratamiento. Revista Médica, 8, 56-71.

Maurer, D., \& Vargas, J.A. (1983). Benthic studies in the Gulf of Nicoya, Costa Rica. Progress Report of the International Cooperative Assistance Program of Sea Grant. University of Delaware.

Glynn, P.W. (1984). An amphinomid worm predator of the crown-of-thorns sea star and general predation on asteroids in Eastern and Western Pacific corals. Bull. Mar. Sci., 35, 54-71.

Hay, M.E. (1984). Patterns of fish and urchin grazing on Caribbean coral reefs: are previous results typical? Ecology, 65, 446-454.

Hendler, G., \& Miller, J.E. (1984). Ophioderma devaneyi and Ophioderma ensiferum new brittlestar species from the western Atlantic (Echinodermata: Ophiuroidea). Proc. Biol. Soc. Wash., 97, 462-491.

Hendler, G. (1984). Brittlestar color-change and phototaxis (Echinodermata: Ophiuroidea: Ophiocomidae). Mar. Ecol., 5(4), 379-401.

Hendler, G. (1984). The association of Ophiothrix lineate and Callyspongia vaginalis: a brittlestar-sponge cleaning symbiosis? Mar. Ecol., 5(1), 9-27.

Lawrence, J.M., \& Glynn, P.W. (1984). Absorption of nutrients from the coral Pocillopora damicornis (L.) by the echinoid Eucidaris thouarsii (val.). Comp. Biochem. Physiol. A Mol. Integr. Physiol., 77, 111-112.

Lessios, H.A. (1984). Possible prezygotic reproductive isolation in sea urchins separated by the Isthmus of Panama. Evolution, 38, 1144-1148.

Lessios, H.A. (1984). Annual reproductive periodicity in eight echinoid species on the Caribbean coast of Panama. Proceedings of the $5^{\text {th }}$ International Echinoderm Conference (pp. 303-311). Galway, Ireland.

Lessios, H.A., Cubit, J.D., Robertson, D.R., Shulman, M.J., Parker, M.R., Garrity, S.D., \& Levings, S.C. (1984). Mass mortality of Diadema antillarum on the Caribbean coast of Panama. Coral Reefs, 3, 173-182.

Lessios, H.A., Robertson, D.R., \& Cubit, J.D. (1984). Spread of Diadema mass mortality through the Caribbean. Science, 226, 335-337.

Maurer, D., Epifanio, C., Dean, H., Howe, S., Vargas, J.A., Dittel, A., \& Murillo, M.M. (1984). Benthic invertebrate of a tropical estuary: Gulf of Nicoya, Costa Rica. J. Nat. Hist., 18, 47-61.

Miller, J. E. (1984). Sytematics of the ophidiasterid sea stars Copidaster lymani A. H. Clark, and Hacelia superba H. L. Clark (Echinodermata: Asteroidea) with a key to species of Ophidiasteridae from the West Atlantic. Proc. Biol. Soc. Wash., 97, 194-208.

Miller, J.E., \& Pawson, D.L. (1984). Holothurians (Echinodermata: Holothuroidea). Mem. Hourglass Cruises, 6, 1-79.

Murillo, M.M., \& Cortés, J. (1984). Alta mortalidad en la población del erizo de mar Diadema antillarum Philippi (Echinodermata: Echinoidea), en el Parque Nacional Cahuita, Limón, Costa Rica. Rev. Biol. Trop., 32, 167-169.

Emlet, R.B. (1985). Functional Morphology and Ecology of Larvae of Clypeasteroid Echinoderms and other Ciliated Larvae [Ph.D. Dissertation, University of Washington].

Glynn, P.W. (1985). Corallivore population size and feeding effects following El Niño (1982-83) associated coral mortality in Panama. Proceedings of the 5th International Coral Reef Symposium (pp. 183-188). Tahiti, French Polynesia.

Glynn, P.W. (1985). El Niño associated disturbance to coral reefs and post disturbance mortality by Acanthaster planci. Mar. Ecol. Prog. Ser., 26, 295-300.

Lessios, H.A. (1985). Genetic consequences of mass mortality in the Caribbean sea urchin Diadema antillarum. Proceedings of the 5th International Coral Reef Congress (pp. 371-393). Tahiti, French Polynesia. 
Lewis, S.M., \& Wainwright, P.C. (1985). Herbivore abundance and grazing intensity on a Caribbean coral reef. J. Exp. Mar. Biol. Ecol., 87, 215-228.

Cubit, J.D., Winsor, D.M., Thompson, R.C., \& Burgett, J.M. (1986). Water-level fluctuations, emersion regimes, and variations of echinoid populations on a Caribbean reef flat. Estuar. Coast. Shelf. Sci., 22, 719-737.

Emlet, R.B. (1986). Facultative planktotrophy in the tropical echinoid Clypeaster rosaceus (Linnaeus) and a comparison with obligate planktotrophy in Clypeaster subdepressus (Gray) (Clypeasteroida, Echinoidea). J. Exp. Mar. Biol. Ecol., 95, 183-202.

Hendler, G., \& Littman, B.S. (1986). The ploys of sex: relationships among the mode of reproduction, body size and habitats of coral-reef brittlestars. Coral Reefs, 5, 31-42.

Parker, D.A., \& Shulman, M.J. (1986). Avoiding predation: alarm responses of Caribbean sea urchins to simulated predation on conspecific and heterospecific sea urchins. Mar. Biol., 93, 201-208.

Eakin, C.M. (1987). Damselfish and their lawns: a case of plural mutualism. Symbiosis, 4, 275-288.

Foster, S.A. (1987). The relative impacts of grazing by Caribbean coral reef fishes and Diadema: effects of habitat and surge. J. Exp. Mar. Biol. Eco., 105, 1-20.

Foster, S.A. (1987). Territoriality of the dusky damselfish: influence on algal biomass and on the relative impacts of grazing by fishes and Diadema. Oikos, 50, 153-160.

Hay, M.E., Fenical, W., \& Gustafsson, K. (1987). Chemical defence against diverse coral reef herbivores. Ecology, 68, 1581-1591.

Hendler, G., \& Byrne, M. (1987). Fine structure of the dorsal arm plate of Ophiocoma wendti: Evidence for a photoreceptor system (Echinodermata, Ophiuroidea). Zoomorphology, 107, 261272.

Hendler, G., \& Turner, R.L. (1987). Two new species of Ophiolepis (Echinodermata: Ophiuroidea) from the Caribbean Sea and the Gulf of Mexico: with notes on ecology, reproduction and morphology. Contrib. Sci., 395, 1-14.

Lessios, H.A. (1987). Temporal and spatial variation in egg size of 13 Panamanian echinoids. J. Exp. Mar. Biol. Ecol., 114, 217-239.

Maddocks, R.F. (1987). An ostracod commensal of an ophiuroid and other new species of Pontocypria (Podocopida: Cypridacea). J. Crustacean Biol., 7, 727-737.

Vargas, J.A. (1987). The benthic community of an intertidal mud flat in the Gulf of Nicoya, Costa Rica. Description of the community. Rev. Biol. Trop., 35, 299-316.

Byrne, M. (1988). Evidence for endocytotic incorporation of nutrients from haemal sinus by the oocytes of the brittlestar Ophiolepis paucispina. In R.D. Burke, P.V Randewov, P. Lambert, \& R.L. Parsley (Eds.), Echinoderm Biology: Proceedings of the $6^{\text {th }}$ International Echinoderm Conference, Victoria, 23-28 August 1987 (pp. 557-563). Balkema.

Byrne, M., \& Hendler, G. (1988). Arm structures of the ophiomyxid brittlestars (Echinodermata: Ophiuroidea: Ophiomyxidae). In R.D. Burke, P.V Randewov, P. Lambert, \& R.L. Parsley (Eds.), Echinoderm Biology: Proceedings of the $6^{\text {th }}$ International Echinoderm Conference, Victoria, 23-28 August 1987 (pp. 687-695). Balkema.

Glynn, P.W. (1988). El Niño warming, coral mortality and reef framework destruction by echinoid bioerosion in the eastern Pacific. Galaxea, 7, 129-160.

Guzmán, H.M. (1988). Distribución y abundancia de organismos coralívoros en los arrecifes coralinos de la Isla del Caño, Costa Rica. Rev. Biol. Trop., 36, 191-207.

Hendler, G. (1988). Western Atlantic Ophiolepis (Echinodermata: Ophiuroidea): a description of O. pawsoni new species, and key to the species. Bull. Mar. Sci., 42, 265-272. 
Hendler, G. (1988). Ophiuroid skeleton ontogeny reveals homologies among skeletal plates of adults: A study of Amphiura filiformis, Amphiura stimpsonii and Ophiophragmus filograneus (Echinodermata). Biol. Bull., 174, 2029.

Hendler, G., \& Peck, R.W. (1988). Ophiuroids off the deep end: fauna of the Belizean fore-reef slope. In R.D. Burke, P.V Randewov, P. Lambert, \& R.L. Parsley (Eds.), Echinoderm Biology: Proceedings of the $6^{\text {th }}$ International Echinoderm Conference, Victoria, 23-28 August 1987 (pp. 411-419). Balkema.

Kaplan, E.H. (1988). Southeastern and Caribbean Seashores. Peterson Field Guides, Houghton Mifflin Company.

Lessios, H.A. (1988). Populations dynamics of Diadema antillarum (Echinodermata: Echinoidea) following mass mortality in Panamá. Mar. Biol., 99, 515-526.

Lessios, H.A. (1988). Mass mortality of Diadema antillarum in the Caribbean: What have we learned? Annu. Rev. Ecol. Evol. Syst., 19, 371-393.

Maluf, L.Y. (1988). Composition and distribution of the central Eastern Pacific Echinoderms. Natural History Museum of Los Angeles County, Technical Reports, 2, 1-242.

Maluf, L.Y. (1988). Biogeography of the central eastern shelf echinoderms. In R.D. Burke, P.V. Randewov, P. Lambert, \& R.L. Parsley (Eds.), Echinoderm Biology: Proceedings of the $6^{\text {th }}$ International Echinoderm Conference, Victoria, 2328 August 1987 (pp. 389-398). Balkerma.

Pawson, D.L., \& Miller, J.E. (1988). Thyone tanyspeira, a new species of sea cucumber from the Southern Caribbean Sea. Bull. Mar. Sci., 42, 310-316.

Byrne, M. (1989). Ultrastructure of the ovary and oogenesis in the ovoviviparous ophiuroid Ophiolepis paucispina (Echinodermata). Biol. Bull., 176, 79-95.

Jackson, J.B.C., Cubit, J.D., Keller, B.D., Batista, V., Burns, K., Caffey, H.M., Caldwell, R.L., Garrity, S.D., Getter, C.D., Gonzalez, C., Guzmán, H.M., Kaufmann, K.W., Knap, A.H., Levings, S.C., Marshall, M.J., Sterger, R., Thompson, R.C., \& Weil, E. (1989). Ecological effects of a major oil spill on Panamanian coastal marine communities. Science, $243,37-44$.

Kerstitch, A. (1989). Sea of Cortez Marine Invertebrates. A Guide for the Pacific Coast, Mexico to Ecuador. Sea Challengers Publications.

Vargas, J.A. (1989). A three year survey of the macrofauna of an intertidal mud flat in the Gulf of Nicoya: 1905-1919. In O. Magoon, M. Converse, D. Miner, L.T. Tobin, \& D. Clark (Eds.), New York: American Society of Civil Engineers, Proceedings 6th Symposium on Coastal and Ocean Management, Coastal Zone '89. (pp. 1905-1919). American Society of Civil Engineers.

Cobb, J.L.S., \& Hendler, G. (1990). Neurophysiological characterization of the photoreceptor system in a brittlestar, Ophiocoma wendtii (Echinodermata: Ophiuroidea). Comp. Biochem. Physiol., 97, 329-333.

Fischer, R. (1990). Biogenetic and non-biogenetically determined morphologies of the Costa Rican Pacific coast. Z. Geomorph. N.F., 34, 313-321.

Glynn, P.W. (1990). Coral mortality and disturbances to coral reef in the Tropical Eastern Pacific. In P.W. Glynn (Ed.), Global ecological consequences of the 1982-83 El Niño-Southern Oscillation (pp. 55-126). Elsevier.

Lessios, H.A. (1990). Adaptation and phylogeny as determinants of egg size in echinoderms from the two sides of the Isthmus of Panama. Am. Nat., 135, 1-13.

Lessios, H.A., \& Cunningham, C.W. (1990). Gametic incompatibility between species of the sea urchin Echinometra on the two sides of the Isthmus of Panama. Evolution, 44, 933-941.

Rojas G.M.T. (1990). Determinación de cadmio, cromo, cobre, hierro, manganeso, plomo y zinc en el pepino de mar, Holothuria sp. (Echinodermata) del arrecife coralino del Parque Nacional Cahuita, Costa Caribe, Costa Rica [Undergraduate dissertation, Universidad de Costa Rica].

Shulman, M.J. (1990). Aggression among sea urchins on Caribbean coral reefs. J. Exp. Mar. Biol. Ecol., 140, $197-207$. 
Aronson, R.B. (1991). Predation, physical disturbance, and sublethal arm damage in ophiuroids: A Jurassic-Recent comparison. Mar. Ecol. Prog. Ser., 74, 91-97.

Byrne, M. (1991). Reproduction, development and population biology of the Caribbean ophiuroids Ophionereis olivacea, a protandric hermaphrodite that broos its young. Mar. Biol., 111, 387-399.

Eakin, C.M. (1991). The damselfish-algal lawn symbiosis and its influence on the bioerosion of an El Niño impacted coral reef, Uva Island, Pacific Panama [Ph.D. Dissertation, University of Miami]. Scholarship UMiami. https://scholarship.miami.edu/discovery/fulldisplay/alma991031447772602976/01UOML INST:ResearchRepos itory

Lessios, H.A. (1991). Presence and absence of monthly reproductive rhythms among eight Caribbean echinoids off the coast of Panama. J. Exp. Mar. Biol. Ecol., 153, 27-47.

Levitan, D.R. (1991). Skeletal changes in the test and jaws of the sea urchin Diadema antillarum in response to food limitation. Mar. Biol., 111, 431-435.

Robertson, D.R. (1991). Increases in surgeonfish populations after mass mortality of the sea urchin Diadema antillarum in Panama indicate food limitation. Mar. Biol., 111,437-444.

Aronson, R.B. (1992). The effects of geography and hurricane disturbance on a tropical predator-prey interaction. J. Mar. Biol. Ecol., 162, 15-33.

Clark, A.M., \& Downey, M.E. (1992). Starfishes of the Atlantic. Chapman \& Hall.

Cortés, J., Soto, R., Jiménez, C., \& Astorga, A. (1992). Earthquake associated mortality of intertidal and coral reef organisms (Caribbean of Costa Rica). Proceedings of the 7th International Coral Reef Symposium (pp. 235-240). Guam, Micronesia.

Eakin, C.M. (1992). Post-El Niño Panamanian reefs: less accretion, more erosion and damselfish protection. Proceedings of the 7th International Coral Reef Symposium (pp. 387-396). Guam, Micronesia.

Guzmán, H.M., \& Cortés, J. (1992). Cocos Island (Pacific of Costa Rica) coral reefs after the 1982-83 El Niño disturbance. Rev. Biol. Trop., 40, 309-324.

Levitan, D.R. (1992). Community structure in times past: influence of human fishing pressure on algal-urchin interactions. Ecology, 73, 1597-1605.

Bermingham, E., \& Lessios, H.A. (1993). Rate variation of protein and mitochondrial DNA evolution as revealed by sea urchins separated by the Isthmus of Panama. Proc. Nat. Acad. Sci. USA, 90, 2734-2738.

Guzmán, H.M., \& Cortés, J. (1993). Arrecifes coralinos del Pacífico Oriental Tropical: revisión y perspectivas. Rev. Biol. Trop., 41, 535-557.

Bauer, J.C., \& Agerter, C.J. (1994). Isolation of potentially pathogenic bacterial flora from tropical sea urchins in selected west Atlantic and East Pacific sites. Bull. Mar. Sci., 55, 142-150.

Emlet, R.B. (1995). Development mode and species geographic range in regular sea urchins (Echinodermata: Echinoidea). Evolution, 49, 476-489.

Hendler, G. (1995). New species of brittle stars from the Western Atlantic, Ophionereis vittata, Amphioplus sepultus, and Ophiostigma siva, and the designation of a neotype for Ophiostigma isocanthum (Say) (Echinodermata: Ophiuroidea). Contr. Sci., 458, 1-19.

Hendler, G., Miller, J.E., Pawson, D.L., \& Kier, P.M. (1995). Sea Stars, Sea Urchins, and Allies: Echinoderms of Florida and the Caribbean. Smithsonian Institution Press.

Hendrickx, M.E. (1995). Equinodermos. In W. Fischer, F. Krupp., W. Schneider, C. Sommer, K.E. Carpenter, \& V.H. Niem (Eds.), Guía FAO para la identificación de especies para los fines de las pesca. Pacifico Centro-Oriental. Vol I. Plantas e Invertebrados (pp. 637-646). FAO. 
Lessios, H.A. (1995). Diadema antillarum 10 years after mass mortality: still rare, despite help from a competitor. Proc. R. Soc. Lond. B Biol. Sci., 259, 331-337.

Wulff, J.L. (1995). Sponge-feeding by the Caribbean starfish Oreaster reticulates. Mar. Biol., 123, 313-325.

Eakin, C.M. (1996). Where have all the carbonates gone? A model comparison of calcium carbonate budgets before and alter the 1982-1983 El Niño at Uva Island in the Eastern Pacific. Coral Reefs, 15, 109-119.

Lessios, H.A., \& Pearse, J.S. (1996). Hybridization and introgression between Indo-Pacific species of Diadema. Mar. Biol., $126,715-723$.

Lessios, H.A., Kessing, B.D., Wellington, G.M., \& Graybeal, A. (1996). Indo-Pacific echinoids in the tropical east Pacific. Coral Reefs, 15, 133-142.

Aronson, R.B. (1998). Decadal-scale persistence of predation potential in coral reef communities. Mar. Ecol. Prog. Ser., $172,53-60$.

Fong, P., \& Glynn, P.W. (1998). A dynamic size-structured population model: does disturbance control size structure of a population of the massive coral Gardineroseris planulata in the Eastern Pacific? Mar. Biol., 130, 663-674.

Lessios, H.A., Kessing, B.D., \& Robertson, D.R. (1998). Massive gene flow across the world's most potent marine biogeographic barrier. Proc. R. Soc. Lond. B., 265, 583-588.

Lessios, H.A. (1998). Shallow water echinoids of Cayos Cochinos, Honduras. Rev. Biol. Trop., 46 (Suppl. 4), 95-101.

McClanahan, T.R., \& Muthiga, N.A. (1998), An ecological shift in a remote coral atoll of Belize over 25 years. Environ. Conserv., 25(2), 122-130.

Rojas, M.T., Acuña, J.A., \& Rodríguez, O.M. (1998). Metales traza en el pepino de mar Holothuria (Halodeima) mexicana del Caribe de Costa Rica. Rev. Biol. Trop., 46 (Suppl. 6), 215-220.

Ryan, J.D., Miller, J.L., Zapata, Y., Downs, O., \& Chan, R. (1998). Great Corn Island, Nicaragua. In B. Kjerfve (Ed.), CARICOMP: Caribbean coral reef, seagrass and mangrove sites (pp. 95-105). UNESCO.

Solís-Marín, F.A. (1998). Sistemática, distribución y morfología del género Mellita L. Agassiz, 1841 (Echinodermata, Echinoidea, Clypeasteroida) [M.Sc. Thesis, Universidad Nacional Autónoma de México]

Gonzalez, P., \& Lessios, H.A. (1999). Molecular evolution of the sea urchin retroviral-like (SURL) family of transposable elements. Mol. Biol. Evol., 16, 938-952.

Hendler, G., Baldwin, C.C., Smith, D.G., \& Thacker, C.E. (1999). Planktonic dispersal of juvenile brittle stars (Echinodermata: Ophiuroidea) on a Caribbean reef. Bull. Mar. Sci., 65(1), 283-288.

Hendler, G., Grygier, M.J., Maldonado, E., \& Denton, J. (1999). Babysitting brittle stars: heterospecific symbiosis between ophiuroids (Echinodermata). Invertebr. Biol., 118, 190-201.

Hendler, G., Baldwin, C.C., Smith, D.G., \& Thacker, C.E. (1999). Planktonic dispersal of juvenile brittle stars (Echinodermata Ophiuroidea) on a Caribbean reef. Bull. Mar. Sci., 65(1), 283-288.

Humes, A.G., \& Hendler, G. (1999). Biology and taxonomy of species of Ophiopsyllus and Pseudanthessius (Copepoda) associated with brittle stars (Ophiuroidea) in Belize. Bull. Mar. Sci., 65, 699-713.

Lessios, H.A., Kessing, B.D., \& Robertson, D.R. (1999). Phylogeography of the pantropical sea urchin Eucidaris in relation to land barriers and ocean currents. Evolution, 53, 806-817.

McClanahan, T.R. (1999). Predation and the control of the sea urchin Echinometra viridis and fleshy algae in the patch reefs of Glovers Reef, Belize. Ecosystems, 2, 511-523.

Aronson, R.B., Pretch, W.E., Macintyre, I.G., \& Murdoch, T.J.T. (2000). Coral bleach-out in Belize. Nature, 405, 36. 
Cruz, L.G. (2000). Campaña de educación ambiental para la conservación y protección del pepino de mar (Echinodermata: Holothuroidea) en 15 comunidades del Archipiélago de Bocas del Toro y Península Valiente [M.Sc. Thesis, Universidad Santa María La Antigua].

Hendler, G., \& Pawson, D.L. (2000). Echinoderms of the Rhomboidal Cays, Belize: biodiversity, distribution, and ecology. Atoll Res. Bull., 479, 273-299.

Humes, A.G. (2000). Asterocheres crinoidicola n. sp., a copepod (Siphonostomatoida: Asterocheridae) parasitic on crinoids in Belize. Syst. Parasitol., 47(2), 103-110.

McCartney, M.A., Keller, G., \& Lessios, H.A. (2000). Dispersal barriers in tropical oceans and speciation in Atlantic and eastern Pacific sea urchins of the genus Echinometra. Mol. Ecol., 9, 1391-1400.

Eakin, C.M. (2001). A tale of two ENSO events: carbonate budgets and the influence of two warming disturbances and intervening variability, Uva Island, Panama. Bull. Mar. Sci., 69, 171-186.

Fong, P., \& Glynn, P.W. (2001). Population abundance and size-structure of an Eastern Tropical Pacific reef coral after the 1997-98 ENSO: a simulation model predicts field measures. Bull. Mar. Sci., 69(1), 187-202.

Lessios, H.A. (2001). Molecular phylogeny of Diadema: Systematic implications. In M. Barker (Ed.), Echinoderm 2000: Proceedings of the $10^{\text {th }}$ International Echinoderm Conference (pp.487-495). Swets and Zeitinger.

Lessios, H.A., Kessing, B.D., \& Pearse, J.S. (2001). Population structure and speciation in tropical seas: global phylogeography of the sea urchin Diadema. Evolution, 55, 955-975.

Lessios, H.A., Garrido, M.J., \& Kessing, B.D. (2001). Demographic history of Diadema antillarum, a keystone herbivore on Caribbean reefs. Proc. R. Soc. London B., 268, 1-7.

Aronson, R.B., Precht, W.F., Toscano, M.A., \& Koltes, K.H. (2002). The 1998 bleaching event and its aftermath on a coral reef in Belize. Mar. Biol., 141, 435-447.

Aronson, R.B., Macintyre, I.G., Precht, W.F., Murdoch, T.J.T., \& Wapnick, C.M. (2002). The expanding scale of species turnover events on coral reefs in Belize. Ecol. Monogr., 72, 233-249.

Cortés, J., \& León, A. (2002). Arrecifes coralinos del Caribe de Costa Rica. INBio.

Guzmán, H.M., \& Guevara, C.A. (2002). Annual reproductive cycle, spatial distribution, abundance, and size structure of Oreaster reticulatus (Echinodermata: Asteroidea) in Bocas del Toro, Panamá. Mar. Biol., 141, 1077-1084.

Guzmán, H.M., \& Guevara, C.A. (2002). Population structure, distribution and abundance of three commercial species of sea cucumber (Echinodermata) in Panama. Carib. J. Sci., 38, 230-238.

Hasbún, C.R., \& Lawrence, A.J. (2002). An annotated description of shallow water Holothurians (Echinodermata: Holothuroidea) from Cayos Cochinos, Honduras. Rev. Biol. Trop., 50(Suppl. 4), 669-678.

McCartney, M.A., \& Lessios, H.A. (2002). A quantitative analysis of gamete incompatibility between closely related species of neotropical sea urchins. Biol. Bull., 202, 166-181.

Fonseca, A.C. (2003). A rapid assessment at Cahuita National Park, Costa Rica, 1999 (Part 1: Stony corals and algae). Atoll Res. Bull., 496, 248-257.

Fonseca, A.C., \& Arrivillaga, A. (2003). Coral reefs of Guatemala. In J. Cortés (Ed.), Latin American Coral Reefs (pp. 159169). Elsevier Science B.V.

Guzmán, H.M., Guevara, C.A., \& Hernández, I. (2003). Reproductive cycle of two commercial species of sea cucumber (Echinodermata: Holothuroidea) from Caribbean Panama. Mar. Biol., 142, 271-279.

Lessios, H.A., Kane, J., \& Robertson, D.R. (2003). Phylogeography of the pantropical sea urchin Tripneustes: contrasting patterns of population structure between oceans. Evolution, 57, 2026-2036.

Reyes-Bonilla, H., \& Barraza, J.E. (2003). Corals and associated marine communities from El Salvador. In J. Cortés (Ed.), Latin American Coral Reefs (pp. 351-360). Elsevier Science B.V. 
Zigler, K.S., \& Lessios, H.A. (2003). Evolution of bindin in the pantropical sea urchin Tripneustes: Comparisons to bindin of other genera. Mol. Biol. Evol., 20, 220-231.

Alvarado, J.J. (2004). Abundancia del erizo de mar Centrostepanus coronatus (Verrill, 1867) (Echinoidea: Diadematidae) en aguas del Pacífico de Costa Rica. Rev. Biol. Trop., 52(4), 911-913.

Alvarado, J.J., \& Cortés, J. (2004). The state of knowledge on echinoderms of Costa Rica and Central America. In T. Heinzeiller, T., \& J.H. Nebelsick (Eds.), Echinoderms: München (pp. 149-155). Taylor \& Francis Group.

Alvarado, J.J., Cortés, J., \& Salas, E. (2004). Population Densities of Diadema antillarum Philippi (Echinodermata: Echinoidea) at Cahuita National Park (1977-2003), Costa Rica. Caribb. J. Sci., 40(2), 257-259.

McCartney, M.A., \& Lessios, H.A. (2004). Adaptative evolution of sperm bindin tracks egg incompatibility in neotropical sea urchins of the genus Echinometra. Mol. Biol. Evol., 21(4), 732-745.

Roux, M. (2004). New Hyocrinid crinoids (Echinodermata) from submersible investigations in the Pacific Ocean. Pac. Sci., 58(4), 597-613.

Zigler, K.S., \& Lessios, H.A. (2004). Speciation on the coasts of the New World: Phylogeography, reproductive isolation, and the evolution of bindin in Lytechinus. Evolution, 58, 1225-1241.

Alvarado, J.J., \& Fernández, C. (2005). Equinodermos del Parque Nacional Marino Ballena, Pacífico, Costa Rica. Rev. Biol. Trop., 53(Suppl. 3), 275-284.

Aronson, R.B., Macintyre, I.G., Lewis, S.A., \& Hilbun, N.L. (2005). Emergent Zonation and Geographic Convergence of Coral Reefs. Ecology, 86, 2586-2600.

Barraza, J.E., \& Hasbún, C.R. (2005). Los equinodermos (Echinodermata) de El Salvador. Rev. Biol. Trop., 53(Suppl. 3), 139-146.

Bolaños, N., Bourg, A., Gómez, J., \& Alvarado, J.J. (2005). Diversidad y abundancia de equinodermos en la laguna arrecifal del Parque Nacional Cahuita, Caribe de Costa Rica. Rev. Biol. Trop., 53(Suppl. 3), 285-290.

Collin, R., Díaz, M.C., Norenburg, J., Rocha, R.M., Sánchez, J.A., Schulze, A., Schwarts, M., \& Valdés, A. (2005). Photographic identification guide to some common marine invertebrates of Bocas del Toro, Panama. Caribb. J. Sci. , 41, 638-707.

Hendler, G. (2005). Two new brittle star species of the genus Ophiothrix (Echinodermata: Ophiuridae: Ophiotrichidae) from coral reefs in the southern Caribbean Sea, with notes on their biology. Caribb. J. Sci., 41, 583-599.

Lessios, H.A. (2005). Diadema antillarum populations in Panama twenty years following mass mortality. Coral Reefs, 24(1), 125-127.

Lessios, H.A. (2005). Echinoids of the Pacific waters of Panama: status of knowledge and new records. Rev. Biol. Trop., 53(Suppl. 3), 147-170.

McAlister, J.S. (2005). Environmental heterogeneity and the evolution of plasticity in Panamanian echinoid larvae. Integr. Comp. Biol., 45(6), 1040-1040.

Palumbi, S.R., \& Lessios, H.A. (2005). Evolutionary animation: how do molecular phylogenies compare to Mayr's reconstruction of speciation patterns in the sea? Proc. Natl. Acad. Sci. USA, 102(1), 6566-6572.

Stockley, B., Smith, A.B., Littlewood, T., Lessios, H.A., \& Mackenzie-Dodds, J.A. (2005). Phylogenetic relationships of spatangoid sea urchins (Echinoidea): taxon sampling density and congruence between morphological and molecular estimates. Zoologica Scripta, 34(5), 447-468.

Carpenter, R.C., \& Edmunds, P.J. (2006). Local and regional scale recovery of Diadema promotes recruitment of scleractinian corals. Ecol. Lett., 9, 271-280.

Coppard, S.E., \& Campbell, A.C. (2006). Systematic significance of tridentate pedicellariae in the echinoid genera Diadema and Echinothrix. Invertebr. Biol., 125(4), 363-378. 
Newman, M.J.H., Paredes, G.A., Sala, E., \& Jackson, J.B.C. (2006). Structure of Caribbean coral reef communities across a large gradient of fish biomass. Ecol. Lett., 9, 1216-1227.

Wulf, J.L. (2006). Sponge systematics by starfish: Predators distinguish cryptic sympatric species of Caribbean fire sponges, Tedania ignis and Tedania klausi n. sp. (Demospongiae, Poecilosclerida). Biol. Bull., 211, 83-94.

Brown-Saracino, J., Peckol, P., Allen-Curran, H., \& Robbart, M.L. (2007). Spatial variation in sea urchins, fish predators, and bioerosion rates on coral reefs of Belize. Coral Reefs, 26, 71-78.

Carballo-Bolaños, R.E., \& Pocasangre-Orellana, X.M. (2007). Composición y estructura de la fauna intermareal de equinodermos en el sistema arrecifal rocoso Los Cóbanos, Departamento de Sonsonate, El Salvador [Undergraduate dissertation, Universidad de El Salvador].

Guzmán, H.M., \& Cortés, J. (2007). Reef recovery 20 years after the 1982-1983 El Niño massive mortality. Mar. Biol., $151,401-411$.

Myhre, S., \& Acevedo-Gutiérrez, A. (2007). Recovery of sea urchins Diadema antillarum populations is correlated to increased coral and reduced macroalgal cover. Mar. Ecol. Prog. Ser., 329, 205-210.

Richards, V.P., Thomas, J.D., Stanhope, M.J., \& Shivji, M.S. (2007). Genetic connectivity in the Florida reef system: comparative phylogeography of commensal invertebrate with contrasting reproductive strategies. Mol. Ecol., 16, 139-157.

Alvarado, J.J. (2008). Aggregation behavior of the sea urchin Astropyga pulvinata (Lamarck, 1816) (Echinodermata: Echinoidea) in Punta Flor, Bahía Culebra, Costa Rica. Pac. Sci., 62(4), 579-592.

Alvarado, J.J., \& Chiriboga, A. (2008). Distribución y composición de los equinodermos de las aguas someras en la Isla del Coco, Pacifico Oriental, Costa Rica. Rev. Biol. Trop., 56(2), 99-111.

Alvarado, J.J., Solis-Marin, F.A., \& Ahearn, C. (2008). Echinoderms (Echinodermata) from Central America Caribbean. Rev. Biol. Trop., 56, 37-55.

Fonseca, A.C. (2008). Coral reefs of Miskitus Cays, Nicaragua. Gulf Carib. Res., 20, 1-10.

Lessios, H.A. (2008). The Great American Schism: Divergence of marine organisms after the rise of the Central American Isthmus. Annu. Rev. Ecol. Evol. Syst., 39, 63-91.

McAlister, J.S. (2008). Evolutionary responses to environmental heterogeneity in Central American echinoid larvae: plastic versus constant phenotypes. Evolution, 62, 1358-1372.

Toral-Granda, V., Lovatelli, A., \& Vasconcellos, M. (2008). Population status, fisheries and trade of sea cucumbers in Latin America and the Caribbean. In V. Toral-Granda, A. Lovatelli, \& M. Vasconcellos (Eds.), Sea cucumbers. A global review of fisheries and trade (pp. 213-229). FAO Fisheries and Aquaculture Technical Paper.

Vogler, C., Benzie, J., Lessios, H.A., Barber, P., \& Wörheide, G. (2008). A threat to coral reefs multiplied? Four species of crown-of-thorns starfish. Biol. Lett., 4, 696-699.

Zigler, K.S., Lessios, H.A., \& Raff, R.A. (2008). Egg energetics, fertilization kinetics, and population structure in echinoids with facultatively feeding larvae. Biol. Bull., 215, 191-199.

Alvarado, J.J., \& Cortés, J. (2009). Echinoderms. In I.S. Wehrtmann, \& J. Cortés (Eds.), Marine Biodiversity of Costa Rica, Central America (pp. 421-433). Springer.

Enochs, I.C., \& Hockensmith, G. (2009). Effects of coral mortality on the community composition of cryptic metazoans associated with Pocillopora damicornis. Proceedings of the 11th International Coral Reef Symposium (pp. 13681372). Ft. Lauderdale, FL, USA.

Geyer, L.B., \& Lessios, H.A. (2009). Lack of character displacement on the male recognition molecule, bindin, in Atlantic sea urchins of the genus Echinometra. Mol. Ecol. Evol., 26, 2135-2146.

Laguarda-Figueras, A., \& Solís-Marín, F.A. (2009). Holothuria (Cystipus) casoae a new species of sea cucumber (Echinodermata: Holothuroidea) from the Central Eastern Pacific. Sci. Mar., 73, 573-578. 
Marin, I., \& Anker, A. (2009). On the presence of the Pontoniine shirmp, Tuleariocaris holthuisi Hipeau-Jacquotte, 1965 (Decapoda, Pontoniinae) on the Pacific coast of Panama. Crustaceana, 82(4), 505-508.

Alvarado, J.J. (2010). Isla del Coco (Costa Rica) Echinoderms: State of knowledge. In L.G. Harris, S.A. Böttger, C.W. Walker, \& M.P. Lesser (Eds.), Echinoderms: Durham (pp.103-113). CRC Press, Taylor \& Francis Group.

Alvarado, J.J., Solís-Marín, F.A., \& Ahearn, C.G. (2010). Echinoderm (Echinodermata) diversity in the Pacific coast of Central America. Mar. Biodivers., 40, 45-56.

Borrero-Pérez, G.M., Gómez-Zurita, J., González-Wangüemert, M., Marcos, C., \& Pérez-Ruzafa, A. (2010). Molecular systematics of the genus Holothuria in the Mediterranean and Northeastern Atlantic and a molecular clock for the diversification of the Holothuriidae (Echinodermata: Holothuroidea). Mol. Phylogenetics Evol., 57, 899-906.

Cortés, J., Jiménez, C.E., Fonseca, A.C., \& Alvarado, J.J. (2010). Status and conservation of coral reefs in Costa Rica. Rev. Biol. Trop., 58(1), 33-49.

Díaz, J.M., Miloslavich, P., Klein, E., Alvarado, J.J., Díaz, C., Gobin, J., Escobar-Briones, E., Cruz, J.J., Weil, E., Cortés, J., Bastidas, A.C., Robertson, D.R., Zapata, F.A., Martín, A., Castillo, J., Kazandjian, A., \& Ortiz, M. (2010). The State of Knowledge of Caribbean Marine Biodiversity. PLOS ONE, 5, e11916.

Gischler, E. (2010). Possible fossil echinoid mass mortality detected in Holocene lagoons, Belize. Palaios, 25, $260-268$.

Hendler, G., \& Kim, I.H. (2010). Larval biology of Thaumatopsyllid copepods endoparasitic in Caribbean ophiuroids. J. Crustacean Biol., 30, 206-224.

Lawrence, J.M., Pomory, C.M., Sonnenholzner, J., Hiratsuka, Y., \& Molina, L. (2010). Scaling of Aristotle's lantern in sea urchins Lytechinus and Tripneustes. In L.G. Harris, S.A. Böttger, C.W. Walker, \& M.P. Lesser (Eds.), Echinoderms: Durham (pp. 219-224). CRC Press, Taylor \& Francis Group.

Scheibling, R.E., \& Metaxas, A. (2010). Mangroves and fringing reefs as nursery habitats for the endangered Caribbean sea star Oreaster reticulatus. Bull. Mar. Sci., 86, 133-148.

Zulliger, D.E., \& Lessios, H.A. (2010). Phylogenetic relationships in the genus Astropecten Gray (Paxillosida: Astropectinidae) on a global scale: Molecular evidence for morphological convergence, species-complexes and possible cryptic speciation. Zootaxa, 2504, 1-19.

Alvarado, J.J. (2011). Echinoderm diversity in the Caribbean Sea. Mar. Biodivers., 41, 261-285.

Alvarado, J.J., Ayala, A., Del Castillo-Cárdenas, P.A.A., Fernández, C., Aguirre-Rubí, J., Buitrago, F., \& Reyes-Bonilla, H. (2011). Coral communities of San Juan del Sur, Pacific Nicaragua. Bull. Mar. Sci., 87(1), 129-146.

Edgar, G.J., Banks, S.A., Bessudo, S., Cortés, J., Guzmán, H.M., Henderson, S., Martínez, C., Rivera, F., Soler, G., Ruiz, D., \& Zapata, F.A. (2011). Variation in reef fish and invertebrate communities with level of protection from fishing across the Eastern Tropical Pacific seascape. Global Ecol. Biogeogr., 20, 730-743.

Enochs, I.C., Toth, L.T., Brandtneris, V.W., Afflerbach, J.C., \& Manzello, D.P. (2011). Environmental determinants of motile cryptofauna on an eastern Pacific coral reef. Mar. Ecol. Prog. Ser., 438, 105-118.

Melbourne-Thomas, J., Johnson, C.R., Fung, T., Seymour, R.M., Chérubin, L.M., Arias-González, J.E., \& Fulton, E.A. (2011). Regional-scale scenario modelling for coral reefs: a decision support tool to inform management of a complex system. Ecol. Appl., 21, 1380-1398.

Vargas, J.A., \& Solano, S. (2011). On Mellitella stokesii and Amphipholis geminata (Echinodermata), from an intertidal flat in the upper Gulf of Nicoya estuary, Pacific, Costa Rica. Rev. Biol. Trop., 59, 193-198.

Alvarado J.J., Guzmán, H.M., \& Breedy, O. (2012). Distribution and diversity of echinoderms (Asteroidea, Echinoidea, Holothuroidea) in the islands of the gulf of Chiriqui, Panama. Rev. Biol. Mar. Oceanogr., 47(1), 13-22.

Alvarado J.J., \& Vargas-Castillo, R. (2012). Invertebrados asociados al coral constructor de arrecifes, Pocillopora damicornis en Playa Blanca, Bahía Culebra, Costa Rica. Rev. Biol. Trop., 60(2), 77-92. 
Alvarado J.J., Cortés, J., \& Reyes-Bonilla, H. (2012). Reconstruction of Diadema mexicanum A. Agassiz, 1863 bioerosion impact on three Costa Rican Pacific coral reefs. Rev. Biol. Trop., 60(2), 121-132.

Enochs, I.C., \& Manzello, D.P. (2012). Species richness of motile cryptofauna across a gradient of reef framework erosion. Coral Reefs, 31, 653-661.

Enochs, I.C. (2012). Motile cryptofauna associated with live and dead coral substrates: implications for coral mortality and framework erosion. Mar. Biol., 159, 709-722.

Levin, L.A., Orphan, V.J., Rouse, G.W., Rathburn, A.E., Ussler, W., Cook, G.S., Goffredi, S.K., Perez, E.M., Waren, A., Grupe, B.M., Chadwick, G., \& Strickrott, B. (2012). A hydrothermal seep on the Costa Rican margin: Middle ground in a continuum of reducing ecosystems. Proc. R. Soc. B Biol. Sci., 279(1738), 2580-2588.

Reijmer, J.J.G., Bauch, T., \& Schäfer, P. (2012). Carbonate facies patterns in surface sediments of upwelling and nonupwelling shelf environments (Panama, East Pacific), Sedimentology, 59(1), 32-56.

Alvarado, J.J., Barraza, E., \& Sancho-Mejías, T.I. (2013). Central America Echinoderms: Diversity, Ecology and Future Perspectives. In J.J. Alvarado, \& F.A. Solís-Marín, F. (Eds.), Echinoderm Research and Diversity in Latin America (pp. 67-106). Springer.

Rafalowski, S., \& Plante, C. (2013). Non-equilibrium processes structuring benthic bacterial communities following deposit feeding by a sea cucumber. Mar. Ecol. Prog. Ser., 478, 115-126.

Arriaga-Ochoa, J.A., Alvarado, J.J., Solís-Marín, F.A., \& Laguarda-Figueras, A. (2014). Lissothuria caboblanquensis n. sp., a new species of sea cucumber (Holothuroidea: Dendrochirotida: Psolidae) from Costa Rica. Zootaxa, 3802(1), 144-150.

Lemer, S., \& Giribet, G. (2014). On the occurrence of Tuleariocaris neglecta Chace, 1969 (Decapoda, Palaemonidae, Pontoniinae) on Echinometra lucunter (Linnaeus, 1758) (Echinodermata, Echinoidea, Echinometridae) in the archipelago of Bocas del Toro, Panama, Crustaceana, 87(5), 634-638.

Prieto-Rios, E., Solís-Marín, F.A., Borrero-Pérez, G.H., \& Díaz-Jaimes, P. (2014). Phylogeography of Holothuria (Halodeima) inornata Semper, 1868 (Echinodermata: Holothuroidea). Rev. Peru. Biol., 21(2), 155-162.

Sibaja-Cordero, J.A., \& García-Méndez, K. (2014). Variación espacial y temporal de los organismos de un intermareal rocoso: Bahía Panamá, Pacífico Norte, Costa Rica. Revista de Biología Tropical, 62(4), 85-97.

Alvarado, J.J., Beita, A., Mena, S., Fernández-García, C., \& Guzmán, A.G. (2015). Ecosistemas coralinos del Área de Conservación Osa, Costa Rica: análisis estructural y necesidades de conservación. Rev. Biol. Trop., 63(1), 219-259.

Alvarado, J.J., Reyes-Bonilla, H., \& Benítez-Villalobos, F. (2015). Diadema mexicanum, a key species of sea urchin in coral reefs of the Eastern Tropical Pacific: State of knowledge and future perspectives, Rev. Biol. Trop., 63, 135-157.

Bodmer, M.D.V., Rogers, A.D., Speight, M.R., Lubbock, N., \& Exton, D.A. (2015). Using an isolated population boom to explore barriers to recovery in the keystone Caribbean coral reef herbivore Diadema antillarum. Coral Reefs, 34, 1011-1021.

Levin, L.A., Mendoza, G.F., Grupe, B.M., Gonzalez, J.P., Jellison, B., Rouse, G., Thurber, A.R., \& Waren, A. (2015). Biodiversity on the rocks: Macrofauna inhabiting authigenic carbonate at Costa Rica methane seeps. PLOS ONE, 10(7), e0131080:1-e0131080:31.

Quinn-Lampson, S.R., Benito-Sandino, O., Solís-Marín, F.A., Arriaga-Ochoa, J., \& Laguarda-Figueras, A. (2015). First records of echinoderms (Echinodermata) in shallow waters of Corn Island, Caribe, Nicaragua. Rev. Biol. Trop, 63, 27-35.

Richards, V.P., DeBiasse, M.B., \& Shivji, M.S. (2015). Genetic evidence supports larval retention in the Western Caribbean for an invertebrate with high dispersal capability (Ophiothrix suensonii: Echinodermata, Ophiuroidea), Coral Reefs, 34(1), 313-325.

Shalaeva, K., \& Newman, W.A. (2016). Zevinaella-a new barnacle genus (Scalpellomorpha: Arcoscalpellinae) associated with crinoids (Echinodermata) from the Caribbean. Zootaxa, 4072(2), 151-170. 
Syverson, V.J., Messing, C.G., Stanley, K., \& Baumiller, T.K. (2015). Growth, injury, and population dynamics in the extant cyrtocrinid Holopus mikihe (Crinoidea, Echinodermata) near Roatán, Honduras. Bull. Mar. Sci., 91(1), 47-61.

Alvarado J.J., Cortés, J., Guzmán, H.M., \& Reyes-Bonilla, H. (2016). Bioerosion by the sea urchin Diadema mexicanum along Eastern Tropical Pacific coral reef. Mar. Ecol., 37(5), 1088-1102.

Alvarado, J.J., Cortés, J., Guzmán, H.M., \& Reyes-Bonilla, H. (2016). Density, size and biomass of Diadema mexicanum (Echinoidea) in Eastern Tropical Pacific coral reefs. Aquat. Biol., 24, 151-161.

Hayes, F.E., Holthouse, M.C., Turner, D.G., Baumbach, D.S., \& Holloway, S. (2016). Decapod crustaceans associating with echinoids in Roatán, Honduras. Crustacean Research, 45, 37-47.

Messing, C.G. (2016). Porphyrocrinus daniellalevyae n. sp. (Echinodermata: Crinoidea), a sea lily from the tropical western Atlantic with a unique crown pattern, Zootaxa, 4147(1), 1-35.

Sangil, C., \& Guzmán, H.M. (2016). Assessing the herbivore role of the sea-urchin Echinometra viridis: Keys to determine the structure of communities in disturbed coral reefs. Mar. Environ. Res., 120, 202-213.

Alvarado, J.J., Chacón-Monge, J.L., Solís-Marín, F.A., Pineda-Enríquez, T., Caballero-Ochoa, A.A., Solano-Rivera, S., \& Romero-Chaves, R. (2017). Equinodermos del Museo de Zoología de la Universidad de Costa Rica. Rev. Biol. Trop., 65(1), 272-287.

Azofeifa-Solano, J.C., Mena, S., Alvarado, J.J., Chacón-Monge, J.L., Clarke, T.M., Herrera-Correal, J., \& Wehrtmann, I.S. (2017). Echinoderm diversity of a tropical estuary in the largest river basin of the Costa Rican Pacific, Eastern Tropical Pacific. Check List, 13(3), 1-11.

Coppard, S.E., \& Lessios, H.A. (2017). Phylogeography of the sand dollar genus Encope: implications regarding the Central American Isthmus and rates of molecular evolution. Scientific Reports, 7, 11520:1-11520:12.

Cramer, K.L., O’Dea, A., Carpenter, C., \& Norris, R.D. (2017). A 3000 year record of Caribbean reef urchin communities reveals causes and consequences of long-term decline in Diadema antillarum. Ecography, 41, 164-173.

Martín-Cao-Romero, C., Solís-Marín, F.A., Alvarado, J.J., \& Laguarda-Figueras, A. (2017). New record of the starfish ophidiaster ludwigi (Echinodermata: Asteroidea) from the Pacific of Mexico and Costa Rica. Rev. Biol. Trop., 65(1), 253-257.

Paschall, O.C., \& Waters, J.A. (2017). Estimated predation rate of the stalked bourgueticrinid (Crinoidea) Democrinus from Roatán, Honduras. Geol. J., 52(5), 727-732.

Rogers, A., Hamel, J.F., \& Mercier, A. (2017). From life-sustaining to life-threatening: the case of the sea cucumber fishery in Nicaragua. SPC Beche-de-Mer Information Bulletin, 37, 48-50.

Sandino, O.B., Solís-Marín, F.A., Caballero-Ochoa, A.A., Conejeros-Vargas, C.A., Márquez-Borrás, F., Ayala-Aguilera, A.P., \& Laguarda-Figueras, A. (2017). Echinoderms from Nicaragua: New records from the Pacific and South Caribbean. Rev. Biol. Trop., 65(1), 288-298.

Summers, M.M., Messing, C.G., \& Rouse, G.W. (2017). The genera and species of Comatulidae (Comatulida: Crinoidea): Taxonomic revisions and a molecular and morphological guide. Zootaxa, 4268(2), 151-190.

Wulff, J. (2017). Bottom-up and top-down controls on coral reef sponges: disentangling within-habitat and between habitat processes. Ecology, 98, 1130-1139.

Alberti, M., \& Reich, S. (2018). A palaeoecological review of the lower Gatun Formation (Miocene) of Panama with special emphasis on trophic relationships. Palaeobiodiversity and Palaeoenvironments, 98(4), 571-591.

Alvarado, J.J., Beita-Jiménez, A., Mena, S., Fernández-García, C., Cortés, J., Sánchez-Noguera, C., Jiménez, C., \& Guzmán, A.G. (2018). Cuando la conservación no puede seguir el ritmo del desarrollo: Estado de salud de los ecosistemas coralinos del Pacífico Norte de Costa Rica. Rev. Biol. Trop., 66(1), 280-308.

Avalos-Castillo, C., Ortíz-Aldana, J.R., Polanco-Vásquez, F., \& Pacay, A. (2018). Estado poblacional del pepino de mar (Clase Holothuroidea) en el Caribe de Guatemala. Ciencia, Tecnología y Salud, 5(1), 16-24. 
Fahrenbruch, M.L. (2018). 'Like scooping money out of the sea': Chinese luxury seafood consumption, roving bandits, and the boom-and-bust jellyfish fishery on the Miskitu Coast of Nicaragua. J. Lat. Am. Geogr., 17(2), 209-238.

Hernández-Ávila, I., Guerra-Castro, E., Bracho, C., Rada, M., Ocaña, F.A., \& Pech, D. (2018). Variation in species diversity of deep-water megafauna assemblages in the Caribbean across depth and ecoregions. PLOS ONE, 13(8), e0201269:1- e0201269:18.

Martins, L., \& Tavares, M. (2018). A new genus and species of Sclerodactylidae (Echinodermata: Holothuroidea: Sclerothyoninae) from the Pacific coast of Panama, and assignment of Neopentamera anexigua to Sclerothyoninae. Zootaxa, 4429(1), 157-164.

Purcell, S.W., Ngaluafe, P., Lalavanua, W., \& Ceccarelli, D.M. (2018). Market price trends of Latin American and Caribbean sea cucumbers inform fisheries management. Reg. Stud. Mar. Sci., 17, 127-132.

Rogers, A., Hamel, J.F., Baker, S.M., \& Mercier, A. (2018). The 2009-2016 Belize sea cucumber fishery: Resource use patterns, management strategies and socioeconomic impacts. Reg. Stud. Mar. Sci., 22, 9-20.

Rogers, A., Hamel, J.F., \& Mercier, A. (2018). Population structure and reproductive cycle of the commercial sea cucumber Holothuria mexicana (Echinodermata: Holothuroidea) in Belize. Rev. Biol. Trop., 66(4), 1629-1648.

Souza, L.S., Rogers, A., Hamel, J.F., \& Mercier, A. (2018). Eulimids (Gastropoda, Eulimidae) on the Sea Cucumber Holothuria mexicana (Ludwig, 1875) (Holothuroidea, Holothuriidae) in Belize. Check List, 14 (5), 923-931.

Sumner-Rooney, L., Rahman, I.A., Sigwart, J.D., \& Ullrich-Lüter, E. (2018). Whole-body photoreceptor networks are independent of 'lenses' in brittle stars, Proc. R. Soc. Lond. B Biol. Sci., 285, 1871:1-1871-8.

Bodmer, M.D.V. (2019). Restoration of the long-spined sea urchin, Diadema antillarum, to Caribbean coral reefs [Ph.D. Dissertation, The Open University].

Cambronero-Solano, S., Benavides, R., Solís-Marín, F.A., \& Alvarado, J.J. (2019). New reports of echinoderms on the Caribbean Continental Shelf of Central America. Zoosymposia, 15(1), 5-12.

Fourriére, M., Alvarado, J.J., Cortés, J., Taylor, M., Ayala-Bocos, A., Heidemeyer, M., Arauz, R., López-Garro, A., \& Wolff, M. (2019). Energy flow structure and role of keystone groups in shallow water environments in Isla del Coco, Costa Rica, Eastern Tropical Pacific. Ecological Modelling, 396, 74-85.

Korzhavina, O.A., Hoeksema, B.W., \& Ivanenko, V.N. (2019). A review of Caribbean Copepoda associated with reefdwelling cnidarians, echinoderms and sponges. Contributions to Zoology, 88, 297-349.

Rogers, A., Hamel, J.F., \& Mercier, A. (2019). Earthquake induces mass-spawning event in two coral-reef sea cucumber species in Belize. Hidrobiológica, 29(1), 49-51.

Sharpe, A.E. (2019). The ancient shell collectors: two millennia of marine shell exchange at Ceibal, Guatemala. Ancient Mesoamerica, 30(3), 493-516.

Collin, R., Venera-Ponton, D.E., Driskell, A.C., Macdonald, K.S., \& Boyle, M.J. (2020). How I wonder what you are: Can DNA barcoding identify the larval asteroids of Panama?. Invertebrate Biology: e12303- e12303. https://doi.org/10.1111/ivb.12303

Collin, R., Venera-Ponton, D.E., Driskell, A.C., Macdonald, K.S., Geyer, L.B., Lessios, H.A., \& Boyle, M.J. (2020). DNA barcoding of echinopluteus larvae uncovers cryptic diversity in neotropical echinoids. Invertebrate Biology: e12292. https://doi.org/10.1111/ivb.12292

Collin, R., Venera-Ponton, D.E., Paulay, G., \& Boyle, M.J. (2020). World Travelers: DNA Barcoding Unmasks the Origin of Cloning Asteroid Larvae from the Caribbean. Biological Bulletin, 239 (2), https://doi.org/10.1086/710796

Cramer, K.L., O'Dea, A., Leonard-Pingel, J.S., \& Norris, R.D. (2020). Millennial-scale change in the structure of a Caribbean reef ecosystem and the role of human and natural disturbance. Ecography, 43(2), 283-293.

Granja-Fernández, R., Pineda-Enríquez, T., Solís-Marín, F. A., \& Laguarda-Figueras, A. (2020). Ophioderma hendleri sp. nov. (Echinodermata: Ophiodermatidae), and its congeners from the Eastern Pacific. European Journal of Taxonomy, 729, 11-41. DOI: https://doi.org/10.5852/ejt.2020.729.1187 
McClanahan, T.R., \& Muthiga, N.A. (2020). Change in fish and benthic communities in Belizean patch reefs in and outside of a marine reserve, across a parrotfish capture ban. Mar. Ecol. Prog. Ser., 645, 25-40.

Sharpe, A.E., Inomata, T., Triadan, D., Burham, M., MacLellan, J., Munson, J., \& Pinzón, F. (2020). The Maya Preclassic to Classic transition observed through faunal trends from Ceibal, Guatemala. PLOS ONE, 15(5), e0233193:1e0233193:42.

Shulman, M.J. (2020). Echinometra sea urchins on Caribbean coral reefs: Diel and lunar cycles of movement and feeding, densities, and morphology. J. Exp. Mar. Biol. Ecol., 530-531, 151430:1-151430:15.

Varela-Sánchez, A., Templado, J., \& Machordom, A. (2020). Aproximación morfológica y molecular al conocimiento de las ofiuras (Echinodermata: Ophiuroidea) en el Parque Nacional Marino Las Baulas (Pacífico Norte, Costa Rica), Rev. Biol. Trop., 68(3), 803-817.

Veitch, M.A., \& Baumiller, T.K. (2020). Low predation intensity on the stalked crinoid Democrinus sp. (Echinodermata) in Roatán, Honduras reveals deep water as likely predation refuge. Bull. Mar. Sci., 97(1), 107-128. 